\title{
Subsistence and Economy at the Calchaquí Valley (Salta, Argentina) during the Regional Developments Period (ca. 1000-1430 AD): Zooarchaeology of Las Pailas locality
}

\author{
Carlos Raúl Belotti López de Medina \\ Museo etnográfico J. B. Ambrosetti, Facultad de Filosofía y Letras, Universidad de Buenos Aires, Moreno 350, zip. 1091, Ciudad Autónoma de Buenos Aires, Argentina
}

\section{A R T I C L E I N F O}

Article history:

Received 6 March 2015

Received in revised form 7 September 2015

Accepted 5 October 2015

Available online $\mathrm{xxxx}$

\section{Keywords:}

Calchaquí Valley

Regional Developments

Las Pailas

Zooarchaeology

\begin{abstract}
A B S T R A C T
A detailed analysis of two faunal assemblages from Las Pailas - SsalCac18 (1) archaeological locality, in the northern section of the Calchaquí Valley (Salta province, Argentina), dated to the Regional Developments Period (ca. AD 1000-1430), is presented. Las Pailas was a large urban settlement, inhabited throughout most of the aforementioned Period. The assemblages come from two trash-dumps of different sizes. The smaller one (Structure 2) was found in a space formed between the walls of two rooms. The other dump (Test pit 3) is much bigger, it belongs to a 140 centimeters thick archaeological deposit situated in the town's outer limits. As both assemblages reflect different lengths of time of accumulation, the analysis was aimed at approaching the relationship between a global strategy for the management of faunal resources at Las Pailas (Test pit 3), and its adaptation to particular constraints in a shorter time (Structure 2). The data presented here contributes to enlarge our knowledge of the geographical and historical variability of the zooarchaeological record of the center and northern Calchaquí Valley.
\end{abstract}

(c) 2015 Elsevier Ltd. All rights reserved.

\section{Introduction}

Zooarchaeological research has developed significantly for the last thirty years at Northwestern Argentina, contributing, among other issues, to our present knowledge on the economy of pre-Hispanic agropastoralist societies ( $c a .1000 \mathrm{BC}-\mathrm{AD} 1530$ ). The animal component of that economy could best be described as a strategy primarily specialized on llama herding, and secondarily in the hunting of northern guanaco and vicuña (cf. Yacobaccio et al., 1997-1998). The three species belong to the Camelidae family and were critical resources among preHispanic peoples; first providing food and raw materials, like wool; also, the llama served as a cargo animal. Current research suggests some geographic and temporal variation for this strategy, which has been explained thus far by environmental, techno-economic and political factors (e. g. Belotti López de Medina, 2015; Izeta, 2007, 2008; Olivera, 1997, Mercolli, 2010).

However, published data remains scarce or uneven for most areas, and all of the inferred trends encompass a great deal of space and time averaging (sensu Lyman, 2003). This lack of information is often substituted by assuming homologies between the zooarchaeological records of different areas. This approach is plausible only as a set of provisional hypotheses in sight of the known spatiotemporal variability of other relevant records (paleoenvironmental, archaeological), and of the various models currently in use among archaeologists working in

E-mail address: crbelotti@gmail.com. the Northwest. Ecological and social variations could have implied different constraints and demands on economic choices and on animal resources, requiring a fine-grained approach and a better zooarchaeological database.

Our study area, the central and northern sections of the Calchaquí Valley (Salta Province, Argentina), is exemplary of this problem. The Valley is at the center of recent debates over the various degrees of social inequality reached by northwestern polities since AD 1000 . Simultaneously, zooarchaeological data is scarce, with only one known assemblage for the Formative Period (ca. 500 BC - AD 1000), and three for the Regional Developments Period (also Late Period, $c a$. AD 1000-1430). The corollary is that relevant lines of research on social complexity are lacking, like zooarchaeological evidence of differential access to staple foods or of patterns of secondary exploitation linked to political economy (e. g. caravan transport of prestige items).

Another problem with the zooarchaeological record of the Calchaquí Valley is that the few known faunal assemblages seem to vary significantly in their taxonomic composition and age profiles, even among coeval sites (e. g. Izeta et al.,, 2009b). Variation could be interpreted as a random error for small assemblages or as the product of specific taphonomic biases, and in both cases ignored as evidence is averaged for the sake of inferring temporal trends on a regional scale. A different approach is explored here: based on contextual information, stratigraphy and the raw volume of faunal evidence, assemblages are placed on a continuum between the short-term choices of individual agents or small social systems (e. g. a household), and the concurrence of recursive action by many agents or groups for a longer span of time. 
To advance on both problem, this paper reports the results of the analysis of two archaeofaunal assemblages excavated in the early 1970s (Tarragó, 1980) at Las Pailas archaeological locality (SsalCac18(1)), in the northern section of the Calchaquí Valley. SSalCac18(1) is a densely aggregated urban settlement and analyzed assemblages come from two distinct discard areas. The first one is Structure 2 (S2), a small dump enclosed between the walls of two compounds of residential structures. The second one is Test Pit 3 (TP3), a $1.4 \mathrm{~m}$ deep excavation of a trash midden, located in the southern limits of the settlement. As a working hypothesis, it is assumed that $\mathrm{S} 2$ shows a smaller range of punctual, tactical, decisions within the framework of a domestic unit's economy, while TP3 offers a time-averaged record of faunal exploitation by a higher number of agents. On this assumption, assemblages are compared to each other first, and then they are contrasted to published zooarchaeological data from central and northern Calchaquí Valley for ca. AD 0-1400. The general objective is to inquire on coeval variability among different kinds of assemblages within the settlement and the valley, as well as on the long term evolution of the Valley' record compared to that of other valleys from Northwestern Argentina.

\section{Literature review}

\subsection{Study area: the Calchaquí Valley}

The study area of the present paper covers the central and northern sections of the Calchaquí Valley, which is included in a greater Calchaquí Area and in the Hills and Valleys ecological zone. The Calchaquí Area (or Calchaquí valleys, plural) is a system of interconnected intermontane valleys running along the Cerro Colorado-Santa María-Calchaquí river basin (Figs. 1.A and 2), including the Cajón and Yocavil valleys to the south (Catamarca and Tucuman provinces) and the Calchaquí Valley to the north (Salta province), as well as their tributaries.

The Calchaquí Valley proper extends over $220 \mathrm{~km}$ (north-south axis) and has a maximum width of $10 \mathrm{~km}$ to the south; the main collector of the basin is the Calchaquí River (Santillán de Andrés, 1982; Williams et al., 2005). The Calchaquí River joins the Santa María River and the Yocavil Valley near the Cafayate town (Fig. 2). Rains oscillates around $150-200 \mathrm{~mm}$ a year and annual mean temperature varies between $12^{\circ}$ C (La Poma, north) and $18^{\circ} \mathrm{C}$ (Cafayate, south) (Valencia and Lago, 1970). The landscape is semiarid with forest and pre-puna vegetation
(Burkart et al., 1999; DeMarrais, 2001). SSalCac18(1) is located at the northern section of the Calchaquí Valley, which runs between the modern settlements of La Poma and Cachi approx. (Fig. 2).

Currently, archaeologists divide Northwestern Argentina in three main ecological zones (Fig. 1.A). The Hills and Valleys zone is a group of semiarid warm intermontane basins between 1500-3000 m asl, suitable for irrigation agriculture, especially at valley floors and alluvial fans (González and Pérez Gollán, 1972; Olivera, 2001). This zone includes the Calchaquí Area and other valleys and gorges of great archaeological significance. These valleys are flanked by two other ecological zones: to the west by the dry Puna -a southern prolongation of the Bolivian Highland- at $3500+\mathrm{m}$ asl; and to the east by humid montane forests -or yungas-, which grow through the eastern Andean slopes (300-3000 m asl). The specific economic potentials of each zone promoted various strategies for appropriation of allochthonous goods by pre-Hispanic peoples.

\subsection{Pre-Hispanic agropastoralist societies of the Calchaquí Valley}

Northwestern Argentina belongs to the Andean cultural macro-area and its trajectory broadly mirrors the main trends of Central and South-Central Andes, from the domestication of plants and animals and the establishment of sedentary lifeways, to the development of increasingly complex levels of political integration (e. g. chiefdoms), and ultimately their subjection to the Inka empire. These parallelisms could be attributed partly to vast social networks that linked Northwestern Argentina to the remaining South-Central Andes, and by a shared cultural substratum. As should be expected, alongside these common patterns, the prehistory of the Northwest exhibits many original features.

The timespan under study, AD 0-1430, roughly encompasses two archaeological periods described for the Calchaquí Area: 1) the Formative (500 BC - AD 1000), and; 2) Regional Developments (AD 1000-1430). Fig. 1.B shows this cultural sequence as well as general chronologies for Northwestern Argentina and the Central Andes (cf. DeMarrais, 2001; González, 1998; Lumbreras, 2008; Scattolin, 2007).

The Formative Period of Northwestern Argentina begins around $500 \mathrm{BC}$. It is a stage characterized by the rise of sedentary lifeways, largely based on economies with a dominant productive component (agriculture or herding), plus the incorporation of new technologies (e. g. pottery). Their political organization has been described as non-ranked, egalitarian,

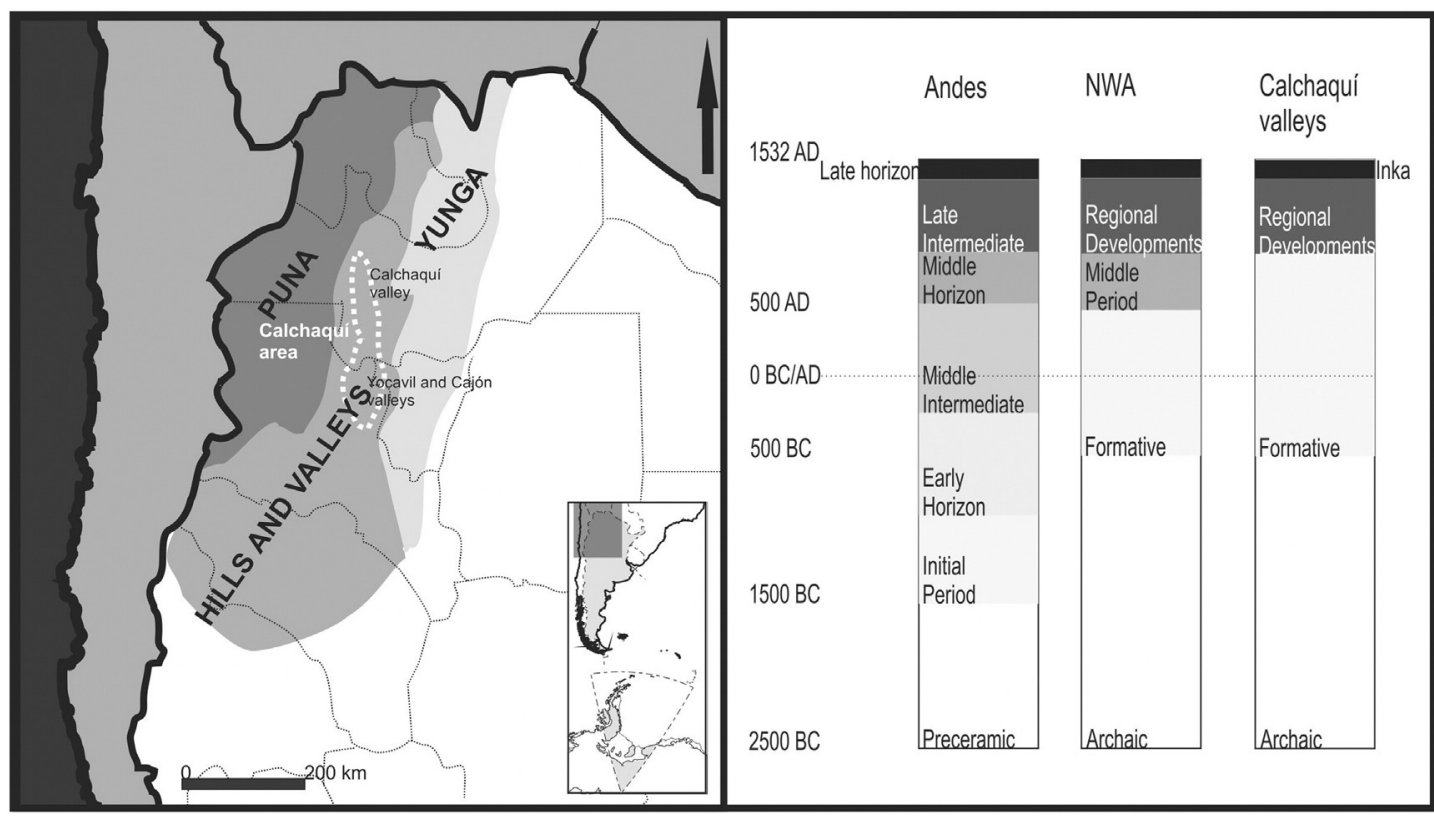

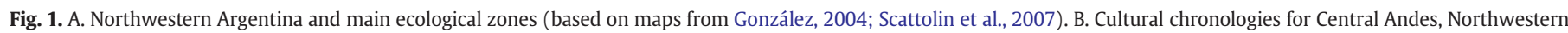
Argentina, and Calchaquí area. 


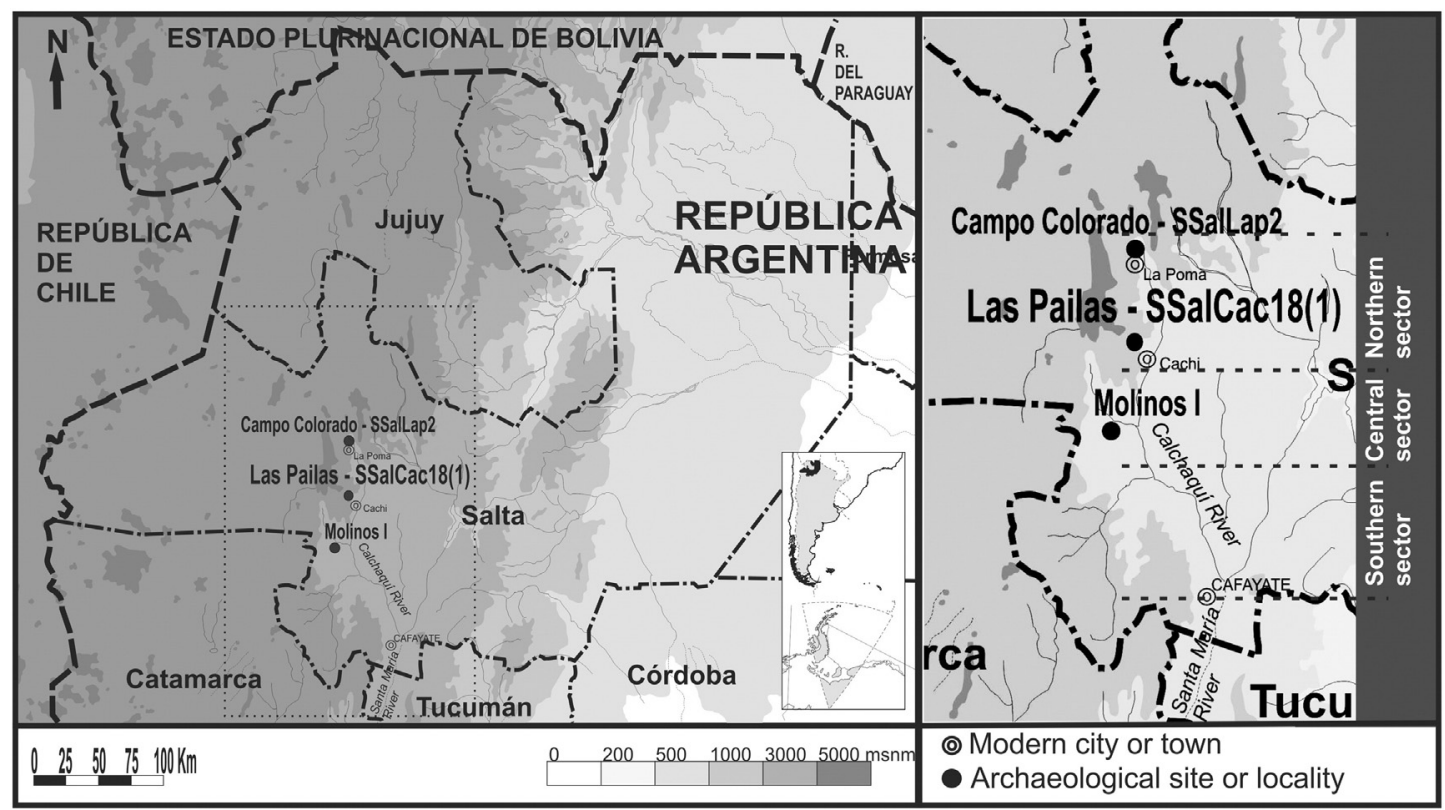

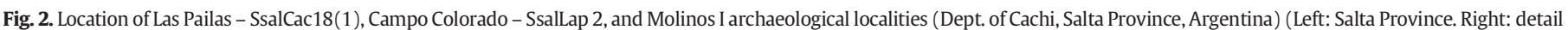
of the Calchaquí Valley).

or tribal (Albeck, 2000; Olivera, 2001). The archaeological record for the Calchaquí Formative Period is broadly similar to that of other valleys of Northwestern Argentina, beginning ca. 500-100 BC (DeMarrais, 2001). There is no conclusive evidence of Aguada influence on the Calchaquí area (Aguada is the defining culture of the Middle Period, v. Fig. 1.B), and hence the Formative has been extended locally to $c a$. AD 900-1000 (DeMarrais, 2001; Scattolin, 2007).

The Regional Developments Period began ca. AD 950, and ended in the $15^{\text {th }}$ century, with the conquest of the Northwest by the Inka rulers. Regional Developments designates an evolutionary threshold, as polities of Northwestern Argentina reached a degree of complexity far from that of the egalitarian villages of the Formative Period. Regional Developments polities are characterized as chiefdoms (Tarragó, 2000), or as segmentary systems known as curacazgos (kuraka is the one of the names given to traditional Andean chiefs) (Nielsen, 2006; Tarragó, 2011). The most telling evidence of social complexity is the extensive diffusion of a characteristic urban settlement pattern, distinguished for having its center at the top of mounts, plateaus or mountain buttresses. This kind of sites is known as pukara (fortress). Innovations of the Regional Developments were possible in part due to a long-term process of population growth and economic intensification dating back to $c a$. AD 400 (v. Scattolin, 2006; Tarragó, 1992).

Regional Developments acknowledges many regional variations through the Northwest. At the beginning of the Regional Developments, smaller villages and isolated dwellings were abandoned in the northern tract of the Calchaquí Valley, while its tributary ravines became densely occupied (DeMarrais, 2001). In a subsequent phase, many sites were established on high terrains, and some of them were encircled by walls (DeMarrais, 2001). As for the central tract of the Calchaquí Valley, densely aggregated settlements developed on the slopes of alluvial terraces since $c a$. AD 800-900 (Baldini et al., 2004). Rural sites were dominant at the margins of western tributaries, characterized by big agricultural facilities and dispersed residential units (Baldini et al., 2004). There are at least eleven pukara-type settlements along the Calchaquí Valley (Tarragó, 2000).

The hypothesis of a hierarchical organization for Regional Developments polities, or at least of its ubiquity through the whole of Northwestern Argentina, has been questioned recently by some researchers. From the analysis of burials and settlement patterns, Acuto argued that the northern Calchaquí polities were in fact more communitarian than previously proposed (Acuto, 2007, Acuto et al., 2011), lacking hierarchies beyond non-hereditary leaderships. One of the cases cited by Acuto in support of this hypothesis is Las Pailas. In a similar vein, DeMarrais (2013) describes the polities of the Calchaquí Valley as heterarchies.

\subsection{Zooarchaeology of the central and northern Calchaquí Valley}

In the last thirty years, zooarchaeology has demonstrated its relevance for the study of pre-Hispanic societies of Northwestern Argentina. The growing body of data allowed the inference of some global trends, the most notorious being the critical role played by camelids as a resource since 9000 BP (Olivera, 1997). At present, the Northwest hosts three species of Camelidae (tribe Lamini): two of them are wild -northern guanaco (Lama guanicoe cacsilensis (Lönnberg, 1913)) and southern vicuña (Vicugna vicugna vicugna (Molina, 1782)); and one is domestic -llama (Lama glama (Linnaeus, 1758)) (Vilá, 2012). Diverse lines of research have established that the llama is descended from the northern guanaco; the earliest evidences of its domestication dating back to ca. $5000 \mathrm{BP}$ (Olivera, 1997; Vilá, 2012; Yacobaccio, 2001). During the Formative Period and thereafter, llama herding played a critical role among agro-pastoralist societies: they provided a reliable source of meat, raw materials and workforce. Llama caravans made possible to carry and exchange goods, from the lowland forests at the eastern slopes of Andes, to the Highland and Sierra, the Pacific coast, etc., and so they contributed to articulation of the vast Andean area and to diffusion of sociocultural innovations (Dillehay and Nuñez Atencio, 1988). Still, the hunting of guanaco and vicuña wild species continued being a critical activity (Izeta, 2008; Yacobaccio et al., 1997-1998). People also hunted small and middle sized vertebrata (big rodents, armadillos, etc.), but their economic or nutritional role seems to have been far behind that of camelids.

Available evidence suggests that the variability of temporal and geographical trends of camelid exploitation is attributable to different sets of causes (environmental, techno-economic and social). In a recent work, Izeta (2008) observes differing lines of development for hunting and herding of camelids between the Puna and the southern Calchaquí Area, between ca. 2000-1000 BP. The later area is relevant to our present study because of its geographical and historical connections to the Calchaquí Valley, as well as having a bigger zooarchaeological database (Belotti López de Medina, 2011, 2015; Izeta, 2007; Mengoni Goñalons, 2013; Pratolongo, 2008). 


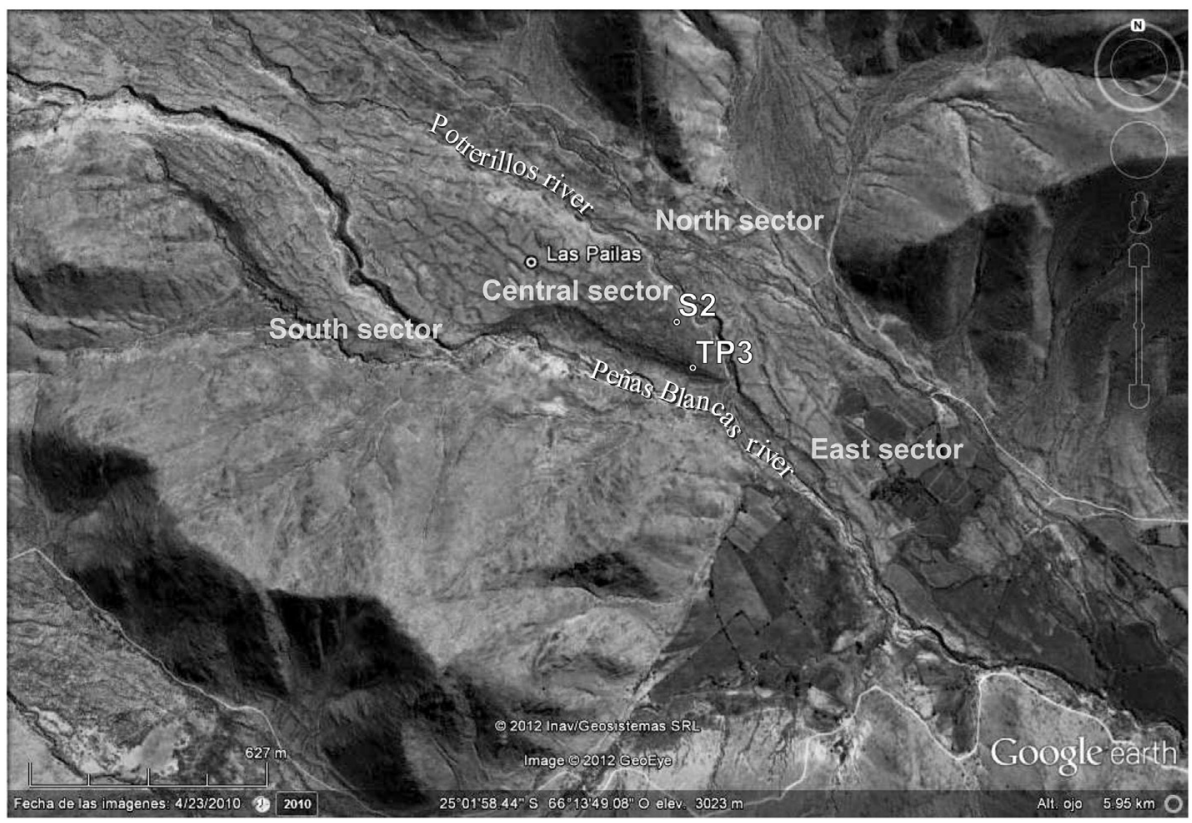

Fig. 3. Satellite photograph of Las Pailas - SsalCac18(1) archaeological locality (Source: Google Earth).

Three main trends were established for the southern Calchaquí Area (Belotti López de Medina, 2015; Izeta, 2007, 2008): 1) a slight increase of taxonomic diversity of faunal assemblages since ca. AD 850 (more small and medium-sized vertebrates); 2) a growing ratio of llama against wild camelids, and; 3 ) a growing ratio of mature camelids. Some of the same trends have been posited for other valleys (e. g. Humahuaca gorge, v. Mercolli, 2010).

The evolution of Camelidae age-profile has been interpreted as a turn towards the conservation of mature llamas for secondary exploitation wool, cargo, etc. (Izeta, 2007). Reduction of big-game hunting could have been due to various causes, ranging from competence between domestic and wild ungulates, to an increase of territoriality between polities.
Increase of hunting-collection of middle and small animals could have been complementary to conservation of mature llamas (Izeta, 2007). Another hypothesis is that intensification of acquisition of small animals could be related to a structural contradiction between subsistence activities of peasant households and a centralized management of surplus during the Regional Developments and Inka periods (Belotti López de Medina, 2010, 2015).

Unlike the southern Calchaquí area, detailed zooarchaeological data published for the Calchaquí Valley is scarce. These are previous works in the archaeological sites of Campo Colorado, Las Pailas, and Molinos I (Fig. 2). Campo Colorado-SSalLap2 is a Formative village, dated to $1875 \pm 70 \mathrm{BP}$ (SI-1221). The faunal remains come from a

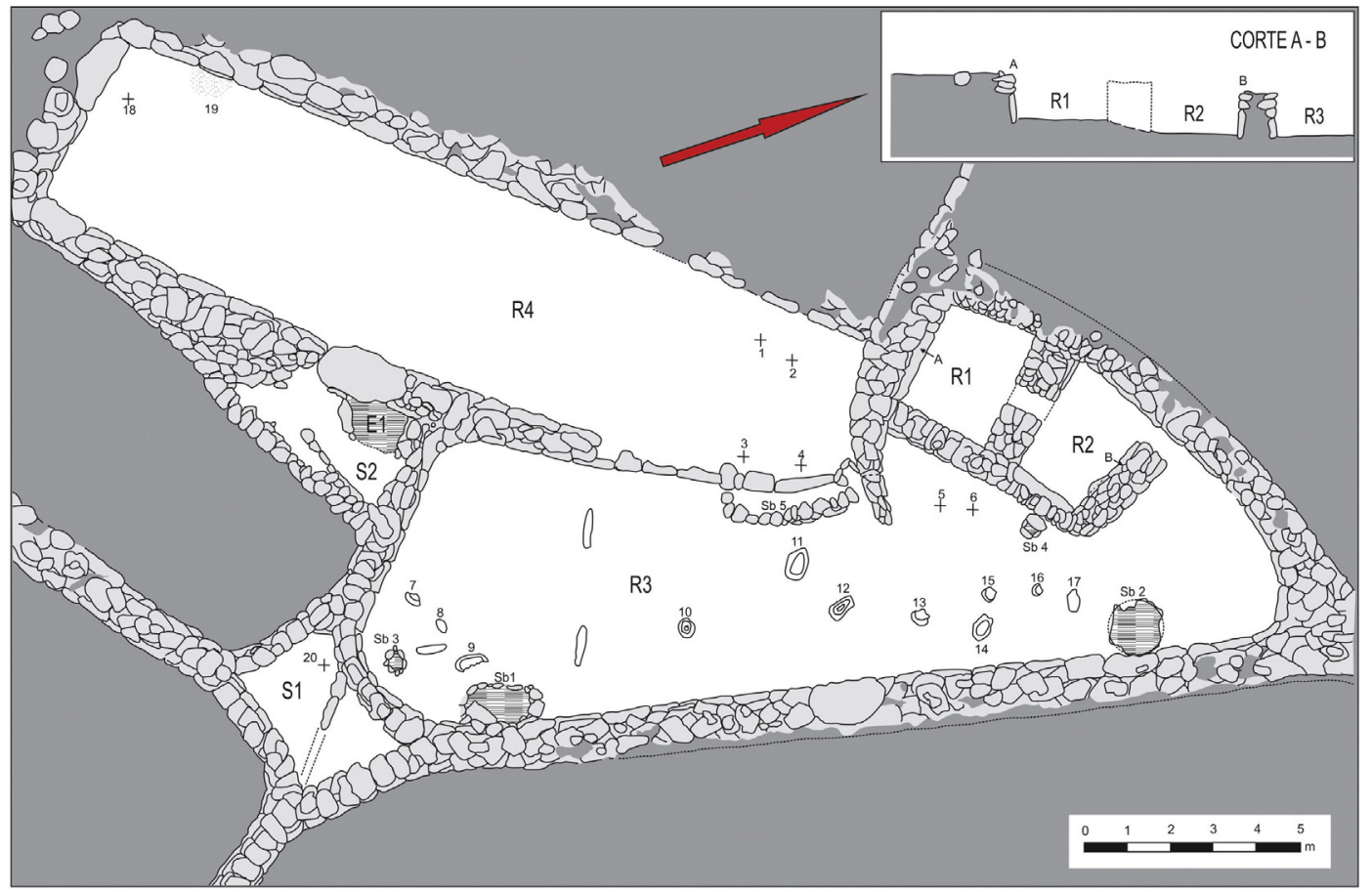

Fig. 4. Excavated residential unit at Las Pailas - SSalCac18(1). (Site layout, original version first published in Tarragó, 1980). 
Table 1

SSalCac18(1)-S2, analyzed specimens (NSP).

\begin{tabular}{llr}
\hline Taxon & Body size class & NSP \\
\hline Artiodactyla & $3-4$ & 8 \\
Artiodactyla & 4 & 5 \\
Camelidae & 4 & 48 \\
Lama sp. & 4 & 1 \\
Lama glama & 4 & 5 \\
Vicugna vicugna vicugna & 4 & 1 \\
Unidentified & $3-4$ & 29 \\
Unidentified & 4 & 15 \\
Unidentified & 9 & 32 \\
& Total & 144 \\
\hline
\end{tabular}

trash-midden. Its description by de Guerrero (1968) is amongst the first exhaustive zooarchaeological reports for Northwestern Argentina: a list of 458 specimens detailing taxa, element, and age class. It does not specify which criteria or methods were used for identification, nor any other data. A total of 439 specimens (96\%) were identified as Camelidae; of these, 373 bones (84.5\%) belong to young, newborn or unborn animals, 50 were assigned to young-adult or adult animals.

At Las Pailas-SSalCac18 (1), faunal remains were recovered from three test-pits in the outskirts of the settlement, and from an area excavation at a residential compound (Tarragó, 1980) (ex infra). Mengoni Goñalons (1991a) did a preliminary analysis of the fauna found in the test-pits, identifying 363 specimens as Camelidae, while other 13 specimens were assigned to additional taxa (Dasipodidae, Lagidium sp., Felidae, Canidae and Canis lupus familiaris). A third of the specimens of Camelidae belonged to sub-adult or younger age categories (estimated by epiphyseal fusion). However, other animals seem to have been culled around 7-13 years old (tooth wear). A sample of these specimens was subjected to morphometric analysis: $45 \%$ of bones belonged to small camelids (cf. vicuña), while the remaining $55 \%$ are comparable to the guanaco-llama size group. The analysis presented here focuses on the Test-Pit 3 (see below), plus one of the assemblages recovered at the residential unit, and involves a complete re-examination of the former assemblage. Among other things, the reanalysis of Test-Pit 3 includes the application of multivariate morphometric analyses for taxonomic identification, as well as the inclusion of previously lost materials.

Fernández Varela et al. (2001) analyzed the faunal remains recovered at the excavation of a room and a superimposed discard area in the Molinos I site (Molinos I R) (Regional Developments Period, central Calchaquí Valley) (Baldini, 2003). As expected, Camelidae is the most abundant taxon (NISP 311). Izeta et al. (2009b) analyzed the archaeofaunas from two additional rooms (designated R1, and R2). Most of specimens belonged to Artiodactyla indet. (NISP 442), and Camelidae (NISP 48). As for specific identification, three specimens from R1 and one from R2 were assigned to vicuña; another bone from R2 was identified as guanaco.

In sum, Calchaquí Valley is roughly similar to other areas of Northwestern Argentina; above all, Camelidae is the predominant family in the record, and there is a relative increase of mature camelids through the first and second millennia AD. There is no information on camelid species for the Formative Period, and the ratio of llama vs. wild camelids vary among Regional Developments assemblages.

Table 2

SSalCac18(1)-S2, weathering of specimens in size classes 3-4 (NSP $\left.{ }_{3-4}\right)$.

\begin{tabular}{clrrrrr}
\hline \multirow{2}{*}{ Body size } & \multicolumn{7}{l}{ Specimens by weathering stage (NSP) } \\
\cline { 2 - 7 } & 0 & 1 & 2 & 3 & 4 & 5 \\
\hline $3-4$ & 22 & 8 & 3 & 3 & - & 1 \\
4 & 40 & 26 & 9 & - & - & - \\
Totals & 62 & 34 & 12 & 3 & & 1 \\
\hline
\end{tabular}

Table 3

SSalCac18(1)-S2, correlation ( $r_{\mathrm{s}}$ ) MAU\% vs. VD $\mathrm{SA}_{\mathrm{SA}}$ for Camelidae sub-assemblage.

\begin{tabular}{llll}
\hline Element & Scan-sites & $\mathrm{r}_{\mathrm{s}}$ & $\mathrm{p} .<0,05$ \\
\hline General & 48 & -0.206141 & 0,159817 \\
Innominate & 7 & -0.059761 & 0,898727 \\
Femur & 4 & 0.210819 & 0,789181 \\
\hline
\end{tabular}

\section{Material and methods}

\subsection{Provenience of faunal assemblages: the Las Pailas - SsalCac18(1) locality}

Las Pailas is located at the confluence of Potrerillos and Peñas Blancas rivers (25 1' 44.30" S, 66 $13^{\circ}$ '55.46" W) (Cachi Dept., Salta Province, Argentina) (Figs. 2 and 3). The archaeological locality has an area of 390 hectares approx. (Páez et al., 2012), and four main sections were distinguished by Tarragó (1980):

1. Central sector, to the west of the confluence point of both rivers. Is a semi-nucleated settlement. The rooms are of irregular layout, with walls built along the contour lines of the terrain. It continues to the west by many agricultural facilities.

2. North sector, left border of Potrerillo River. Cultivation enclosures (canchones), followed by residential structures to the west.

3. East sector. Between the confluence of both rivers and the Las Pailas Ravine. Cultivation enclosures and dispersed rooms.

4. South Sector, crossing Peñas Blancas River. Cultivation enclosures.

Initial fieldworks at Las Pailas took place between 1972-1973, under direction of Tarragó and Núñez Regueiro (Tarragó, 1980). Excavations focused on the Central sector. Six test-pits were dug around the site, and an area-excavation was conducted on a residential unit composed of four rooms (Fig. 4). In the sub-structure 2 (Sb 2) of R3 -probably a silo- a radiocarbon date of $630 \pm 50$ BP was obtained (Gluzman, 2008). Middens containing archaeofauna were detected at the outskirts of the settlement, and inside dead spaces left between walls of rooms (Tarragó, 1980).

In recent years, research at Las Pailas has been continued by different groups. The archaeological evidence from the 1972-1973 excavations is currently being re-analyzed, under direction of M. Tarragó and L. González (e. g. Carbonelli, 2014; Gamarnik, 2009; Gluzman, 2008, this article).

Recent contributions by other research groups include a detailed survey of agricultural facilities of the Central Sector and its vicinity by Páez et al. (2012). Outside the settlement, cultivation enclosures are smaller, of a near rectangular or irregular layout. Some $800 \mathrm{~m}$ northwest, cultivation enclosures become bigger, of rectangular, sub-rectangular or circular layout. Many contain small round structures, maybe for food-storage. The rate of grinding tools is spatially variable, with a higher frequency of conanas at the settlement, while mortars are more abundant at the agricultural sector. The irrigation network collected water $6.1 \mathrm{~km}$ northwest of the settlement, from Potrerillos River and minor mountain streams.

Acuto (2007) brought forth evidence from Las Pailas in support of his communality model of social organization for the Calchaquí Valley

Table 4

SSalCac18(1)-S2, camelid specimens NISP by age classes and epiphyseal fusion (Age classes: $\mathrm{P}=$ perinatal, $\mathrm{N}=$ neonatal, $\mathrm{Y}=$ young, $\mathrm{I}=$ immature, $\mathrm{M}=$ mature. Epiphyseal fusion: $\mathrm{UF}=$ unfused, $\mathrm{F}=$ Fused).

\begin{tabular}{ccc}
\hline Epiphyseal fusion & Age class range & NISP \\
\hline UF & P-N & 3 \\
& P-Y & 7 \\
F & P-I & 2 \\
& Y-M & 4 \\
& I-M & 8 \\
M & 3
\end{tabular}


Table 5

SSalCac18(1)-S2, anatomical profile for Camelidae.

\begin{tabular}{|c|c|c|c|c|c|c|c|c|c|c|c|c|}
\hline \multirow[b]{2}{*}{ Elemento } & \multirow[b]{2}{*}{ NISP } & \multicolumn{3}{|c|}{ MNE R } & \multicolumn{3}{|c|}{ MNE L } & \multicolumn{3}{|c|}{ MNE A/0 } & \multirow[b]{2}{*}{ MNEC } & \multirow[b]{2}{*}{ MAU\% } \\
\hline & & $\mathrm{F}$ & NF & 0 & $\mathrm{~F}$ & NF & 0 & $\mathrm{~F}$ & NF & 0 & & \\
\hline Skull & 1 & - & - & - & - & - & - & - & - & 1 & 1 & 40.00 \\
\hline Mandible & 2 & - & - & 1 & - & - & - & - & - & - & 1 & 20.00 \\
\hline Loose teeth & 1 & - & - & - & - & - & - & - & - & - & - & 0.00 \\
\hline Cervical v. 3-7 & 1 & - & - & - & - & - & - & - & - & 1 & 1 & 8.00 \\
\hline Thoracic V. & 1 & - & - & - & - & - & - & - & - & 1 & 1 & 3.33 \\
\hline Sacrum & 2 & - & - & - & - & - & - & 1 & 1 & - & 2 & 80.00 \\
\hline Ribs & 3 & - & - & 1 & - & - & - & - & - & 1 & 2 & 3.33 \\
\hline Scapulae & 3 & - & - & - & 1 & - & - & - & - & - & 1 & 20.00 \\
\hline Innominate & 3 & 1 & - & - & 1 & 1 & - & - & - & - & 3 & 60.00 \\
\hline Humerus & 3 & - & 1 & - & 1 & - & - & - & - & - & 2 & 40.00 \\
\hline Radius-ulna & 5 & - & 1 & - & - & 1 & - & - & - & - & 2 & 40.00 \\
\hline Cuneiform & 1 & - & - & - & - & - & 1 & - & - & - & 1 & 20.00 \\
\hline Lunar & 1 & - & - & - & - & - & 1 & - & - & - & 1 & 20.00 \\
\hline Femur & 4 & - & - & - & 2 & 1 & - & - & - & - & 3 & 60.00 \\
\hline Tibia & 8 & 2 & 1 & - & - & 2 & - & - & - & - & 5 & 100.00 \\
\hline Astragalus & 3 & - & - & 2 & - & - & 1 & - & - & - & 3 & 60.00 \\
\hline Calcaneus & 1 & - & - & - & - & 1 & - & - & - & - & 1 & 20.00 \\
\hline Cuboid & 1 & - & - & - & - & - & 1 & - & - & - & 1 & 20.00 \\
\hline Metatarsal & 2 & - & - & 1 & - & - & 1 & - & - & - & 2 & 40.00 \\
\hline Metapodia & 5 & - & - & - & - & - & - & 2 & 1 & - & 3 & 30.00 \\
\hline Phalanx 1 & 4 & - & - & - & - & - & - & 3 & 1 & - & 4 & 20.00 \\
\hline
\end{tabular}

during the Regional Developments. About its settlement pattern, he concluded that there is no evidence of significant differences between residential structures, either of building techniques or quality, neither are formalized public spaces; also, there are no storage complexes indicative of centralized control of agricultural surplus.

Since 2008 the author of the present work is carrying an exhaustive research on the faunal assemblages of the 1972-73 excavations. Final results for two of them are presented next (Figs. 3, 4). The first one comes from midden in the southern slope of the site, in the outskirts of the settlement, were a $1.4 \mathrm{~m}$ deep test-pit was dug (Test Pit 3 or TP3); the second assemblage comes from a test-pit dug on Structure 2 (S2), an accumulation of refuse between walls of R3 and R4 of the excavated residential unit.

\subsection{Zooarchaeological techniques of analysis}

Our goal is to produce relevant data about human behavior. To that end, a taphonomic approach was followed, as advocated by Lyman (1987, 1994), meaning that human behavior is included among the processes that mediate the transition from biotic community to the archaeological record.

The first stage of research was production of primary data, its unit of analysis being the specimen -any complete bone or fragment. Anatomical and taxonomical identification of the specimens was done mainly by morphological criteria, based on comparison to osteological collections curated at the Instituto de Arqueología (Universidad de Buenos Aires), which includes complete skeletons of all mammalian taxa usually found at pre-Hispanic assemblages from Northwestern Argentina, and other source materials (e. g. Benavente et al., 1993; Cohen and Serjeantson, 1996; Galotta and Galotta, 1988). Also, specimens were classified by body-size following a typology proposed by Izeta (2007) for Northwestern Argentina, which includes five size/weight classes for vertebrata: Class 1, very-small animals (e. g. Ctenomys, $0.5 \mathrm{Kg}$ ). Class 2, small animals (e. g. Lagidium viscacia, $1.6 \mathrm{Kg}$ ). Class 3, medium-sized animals (e. g. Pterocnemia pennata $30 \mathrm{Kg}$ ). Class 4, big vertebrates (e. g. Hippocamelus antisensis, $52 \mathrm{Kg}$, L. glama, $120 \mathrm{Kg}$ ). Class 9, indeterminate size/weight.

Additional multivariate morphometric analysis were conducted on a sample of camelid bones, for discrimination of specific morphotypes. Specimens were selected based on the following criteria (von den Driesch, 1976): 1) must not be burnt; 2) should belong to fully grown bones. The sampled bones were measured following Kent (1982) and Izeta et al. (2012), and comparative reference measurements for each species were taken from bibliography (Elkin, 1996; Izeta, 2004; Izeta et al., 2009a) and from osteological collections measured by the author. Next, to the set of specimens of each element were applied the following techniques (Menegaz et al., 1988, StatSoft, Inc., 2004): 1) a similitude matrix by the City-Block distance coefficient for each pair of specimens was obtained, and; 2) similitude matrices were subjected to cluster (Unweighted Pair Group Average method, UPGMA) and Principal Components (PCA) analyses. All analysis were done with the Statistica 7.0 software package (StatSoft inc.).

Indicators of age were recorded for specimens of every taxa, although subsequent quantification was restricted to Camelidae. It was recorded: 1 . fusion of ossification centers of endochondral bones (e. g. epiphyseal fusion of long bones and vertebra for mammals) (Chaix and Méniel, 2005; Reitz and Wing, 1999). Sequences of epiphyseal fusion published by Kent (1982) and Burger and Salazar (2003) for Camelidae were consulted to establish minimum or maximum age of death. 2. Teeth eruption and wear (Hillson, 2005; Wheeler, 1982). With this data specimens of Camelidae were assigned, whenever possible, to different age-classes or intervals of classes: perinatal-neonatal (up to 2-3 months), young (up to 24 months), immature (24-36 months), and mature (36 months). Sexual maturation in south-American camelids occurs around 24 months old (Yacobaccio, 2001); today, first shearing and beginning of training for cargo take place at 36 months old approx. (Madero, 1993-94).

Finally, taphonomic traces, like gnawing marks left by carnivores, roots impressions, butchering marks, fracture morphology, modifications induced by heat, and weathering were recorded for every specimen. The general criteria summarized by Lyman (1994) and Mengoni Goñalons (1999), as well as Behrensmeyer (1978) for weathering, were followed.

The second stage is quantification, and subsequent analysis of secondary data. In order to detect relevant trends in data and to test different hypothesis, various procedures and measures were followed. First, the Number of Specimens (NSP, analyzed specimens, identified or not) and Number of Identified Specimens (NISP, the sum of taxonomically identified specimens) were estimated. These units were used

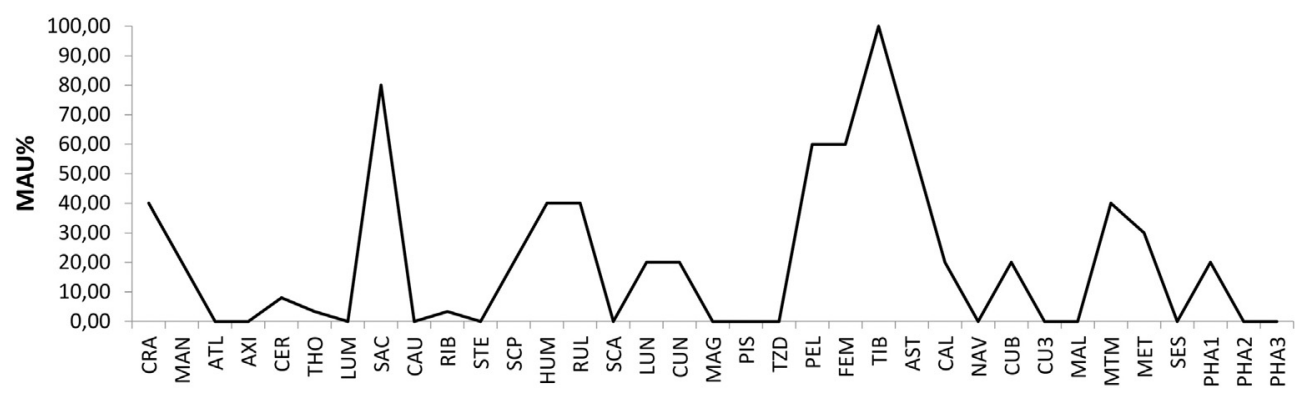

Fig. 5. SSalCac18(1)-S2, MAU\% for Camelidae. 


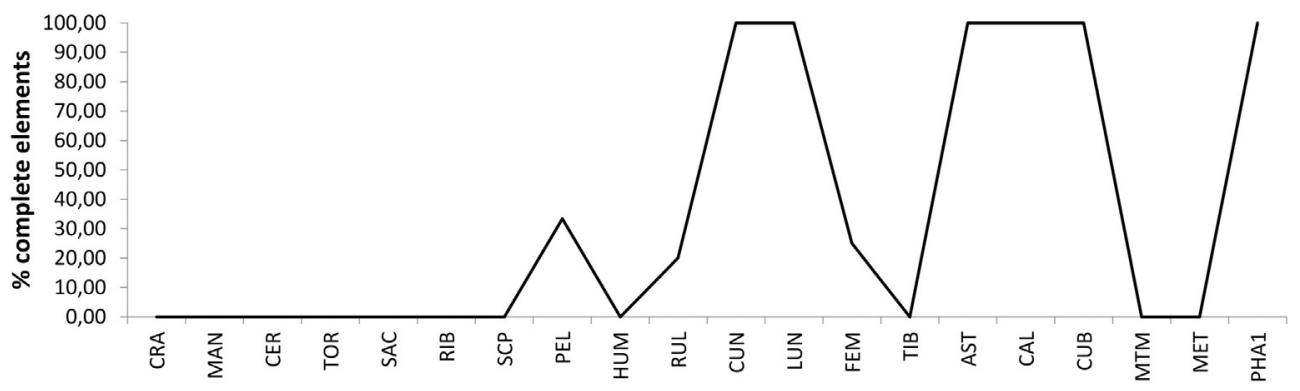

Fig. 6. SSalCac18(1)-S2, percentage of complete bones by anatomical element.

to express abundances of taxa, size and age classes, and frequencies of taphonomic traces.

For the Camelidae sub-assemblage, the following variables were also derived: 1) Minimum Number of Elements (MNE), an estimate of the minimum of individual bones of an element which must have contributed to an assemblage, obtained by the sum of its fractions (Klein and Cruz-Uribe, 1984) and of diagnostic zones (Chaplin, 1971; Mengoni Goñalons, 1999; Morlan, 1994); 2 ) Minimum Number of Individuals (MNI), the minimum number of individual carcasses that account for an assemblage, derived from the MNE (Chaplin, 1971; White, 1953); 3) Minimum Animal Units (MAU), measures the relative abundance among skeletal parts, and is obtained dividing MNE by the number of times an element is present in a complete carcass (Binford, 1984; Mengoni Goñalons, 1999); 4) Standardized MAU values (MAU\%), obtained by dividing the MAU of each element by its highest value for a given assemblage, and multiplying the result by 100 (Binford, 1981).

Anatomic profiles (MNE, MAU) are useful to inquire in some taphonomic problems. First, many attritional processes are mediated by the structural density of bones $\left(\mathrm{g} / \mathrm{cm}^{3}\right)$ (Lyman, 1994), biasing survivorship. To detect such a bias, a Spearman $r$ correlation analysis $\left(r_{s}\right)$ was conducted between two sets of variables: 1 ) shape adjusted volume density values measured by scan-site $\left(\mathrm{VD}_{\mathrm{SA}}\right)$, originally published by Stahl (1999) ${ }^{1}$, vs.; 2) MAU\% estimated by scan-site. As a supplementary control, the analysis was repeated for subsets of data from individual elements with $>3$ scan-sites (Izeta, 2005, 2007; Morlan, 1994).

Also, individual elements vary in nutritional value of associated tissues (meat, marrow, and grease), constraining behavior relating disarticulation, transport and distribution of carcasses. Therefore, a Spearman $r$ analysis of MAU\% by element vs. Food Utility Index (FUI) values for L. glama published by Mengoni Goñalons (1991b) was conducted. As proposed by Marean and Frey (1997), analyses were done separately for long and non-long bones. The same analysis was repeated for MAU\% and bone-marrow cavity volumes.

For description of taxonomic diversity of assemblages, the following measures were taken: 1$)$ Richness (NTaxa), the number of different identified taxa in a given rank (Grayson, 1984; Lyman, 2008; Mengoni Goñalons, 2006-2010); 2) Heterogeneity (H'), the uncertainty of predicting the taxon of a randomly selected specimen, derived by the Shannon-Weaver function; 3 ) Evenness (V'), measures relative abundances amongst taxa, and is derived from heterogeneity (Grayson, 1984; Lyman, 2008; Mengoni Goñalons, 2006-2010; Reitz and Wing, 1999). The taxonomic rank for diversity measures was family, and the base data was NISP by family.

\footnotetext{
1 The volume density values used here were measured by Stahl (1999) at different cross-sections of bones (scan-sites) by dual-energy X-ray absorptiometry (DEXA); then, Stahl adjusted those results according to the bone cross-section surface at the scan-site, obtaining the shape-adjusted bone density (VDsa). Some bones were measured at different points, e. g. the tibia possess five scan-sites.
}

\section{Results, part I. SsalCac18 (1) residential unit, Structure 2}

\subsection{Overview}

The assemblage is composed of 144 specimens, 68 of which were identified (Table 1). The most abundant taxon is Camelidae (NISP 53), of which five specimens were identified as L. glama, and one as $V$. vicugna. The specimen identified as Lama sp. could be either llama, or guanaco. Nowadays, vicuñas are endemic in Puna environments. Their bones could have arrived to Las Pailas by direct exploitation of the highland (hunting), or by exchange. In favor of the former hypotheses, arrow points made of obsidian from Puna sources were identified at SSalCac18(1) (Carbonelli, 2014; Tarragó, 1980). This technology is labor-intensive, aimed to efficiency, and is related to hunting in Puna sites (Escola, 2002).

Only nine specimens exhibited natural traces (carnivore marks NSP 4 , rodent NSP 1 , roots NSP 1 , erosion NSP 3), always from bones in size classes 3-4. Table 2 tallies specimens of classes 3-4 by weathering stage. From a total of 112 specimens, 62 show no sign of weathering, and 34 are in the stage 1 (sequence of Behrensmeyer); one specimen reached the stage 5 of weathering. Given the aforementioned identification of

Table 6

SSalCac18(1)-TP 3, analyzed specimens (NSP).

\begin{tabular}{|c|c|c|c|c|c|c|c|}
\hline \multirow[b]{2}{*}{ Taxon } & \multirow[b]{2}{*}{ Body size class } & \multicolumn{6}{|c|}{ Analyzed specimens by level (NSP) } \\
\hline & & 1 & 2 & 3 & 4 & 5 & 6 \\
\hline Artiodactyla & 3 & - & 1 & - & - & - & - \\
\hline Artiodactyla & $3-4$ & 17 & 12 & 7 & 17 & 13 & 11 \\
\hline Artiodactyla & 4 & 84 & 81 & 36 & 39 & 26 & 26 \\
\hline Camelidae & 3 & 1 & - & - & - & - & - \\
\hline Camelidae & $3-4$ & - & 2 & - & - & 1 & 1 \\
\hline Camelidae & 4 & 125 & 130 & 52 & 107 & 93 & 80 \\
\hline Lama sp. & 4 & 4 & 6 & - & 8 & 1 & 2 \\
\hline Lama glama & 4 & 2 & 8 & - & 1 & 3 & 3 \\
\hline Lama guanicoe cacsilensis & 4 & - & 1 & - & 1 & - & - \\
\hline Vicugna vicugna vicugna & 4 & 2 & 5 & 1 & - & 1 & 2 \\
\hline Cervidae & 4 & - & - & - & - & 1 & - \\
\hline Hippocamelus antisensis & 4 & - & 1 & - & - & 1 & 6 \\
\hline Homo sapiens & 4 & 1 & 2 & - & - & - & - \\
\hline Carnivora & $2-3$ & - & 7 & - & 1 & - & - \\
\hline Canidae & $2-3$ & - & 13 & 1 & - & - & - \\
\hline Chaetophractus vellerosus & 2 & 1 & - & - & 2 & 1 & - \\
\hline Rodentia & 2 & - & - & 1 & - & - & - \\
\hline Lagidium sp. & 2 & 2 & - & - & - & - & 1 \\
\hline AVES & 2 & - & 2 & - & - & - & - \\
\hline Gastropoda & 1 & - & - & - & - & 1 & - \\
\hline Unidentified & $1-2$ & 1 & 1 & - & - & - & - \\
\hline Unidentified & 2 & 4 & 10 & - & - & - & - \\
\hline Unidentified & $2-3$ & 9 & 20 & 5 & 3 & 5 & 2 \\
\hline Unidentified & 3 & - & 7 & - & - & - & - \\
\hline Unidentified & $3-4$ & 406 & 429 & 150 & 309 & 176 & 107 \\
\hline Unidentified & 4 & 106 & 182 & 43 & 109 & 53 & 19 \\
\hline Unidentified & 9 & 542 & 530 & 131 & 302 & 150 & 128 \\
\hline Totals & & 1307 & 1450 & 427 & 899 & 526 & 388 \\
\hline
\end{tabular}


Table 7

SSalCac18(1)- TP 3, weathering of faunal remains for body size classes 3-4 ( $\left.\mathrm{NSP}_{3-4}\right)$.

\begin{tabular}{lrrrrrr}
\hline \multirow{2}{*}{ Body size } & \multicolumn{7}{l}{ Specimens by weathering stage (NSP) } \\
\cline { 2 - 7 } & \multicolumn{1}{c}{1} & \multicolumn{1}{c}{2} & \multicolumn{1}{c}{3} & \multicolumn{1}{c}{4} & 5 \\
\hline 3 & 7 & 2 & 0 & 0 & 0 & 0 \\
$3-4$ & 1089 & 248 & 216 & 62 & 43 & 2 \\
4 & 943 & 217 & 182 & 67 & 42 & 2 \\
Totals & 2039 & 467 & 398 & 129 & 85 & 4 \\
\hline
\end{tabular}

at least two species, it is a reasonable hypothesis that the assemblage accumulated through various episodes of discard, which could partially explain the ample range of weathering stages. On the other hand, there is no specimens in stage 4 .

\subsection{Camelidae sub-assemblage}

\subsubsection{Density-mediated attrition}

First, Minimum Number of Elements (MNE) and Minimum Animal Units (MAU, MAU\%) were estimated according to the aforementioned procedures for 48 scan-sites, each scan-site considered as an anatomical element for purposes of this analysis. Then, Spearman $r$ analyses of MAU\% vs. volume density values $\left(V_{\mathrm{SA}}\right)$ were done, first for the whole sub-assemblage, and second for the innominate and femur scan-sites, to test if anatomical profiles were density-dependent. All analyses provided non-significant results (Table 3 ), so a density bias seems improbable.

\subsubsection{Minimal Number of Individuals and age-profile}

MNI was derived from MNE by segregating two categories of osteological maturation (fused, unfused). A total MNI of four (4) was obtained: two for fused elements, and two for unfused. Among the former, at least one (MNI 1) L. glama, and one (MNI 1) V. vicugna were estimated. It must be observed that minimum numbers, as MNE and MNI, represent an estimation of the minimal values of a certain unit required to account for a given assemblage. But the actual numbers of such unit, be it individual animals or anatomical elements which effectively contributed to the assemblage, could have been greater indeed. Also, minimal numbers could over-represent a given unit, for example a rare taxon which amounts to one or a few specimens, especially if dealing with small assemblages.

Table 4 lists NISP values by stage of epiphyseal fusion (unfused/fused) and by age class. There is at least one very young animal ( $\leq 3$ month old) represented by three specimens (humerus, femur and ilium). Another three fragments came from animals over 36 months old. Two of them are from the left femur, for an MNI of two, and one of them retains a visible fusion line at the head, thus belonging to a young adult. In sum, there is an even ratio of unfused vs. fused specimens (NISP 12:15, MNI $2: 2$ ).

Unfused specimens cannot be identified by morphometric methods, thus it was not feasible to tell if they belonged to llamas, guanacos, or vicuñas. If unfused bones came from domestic animals, this could mean a complex strategy: culling of the very young animals for meat, or even to regulate the growth of herds (cf. Olivera, 1997), or for magic-ritual purposes (cf. Flores Ochoa, 1975; Yacobaccio and Malmierca, 2006); some others could have been culled in their prime for meat production, and, at last; some llamas could have been reserved for reproduction and secondary resources production.

\subsubsection{Anatomical profile}

Table 5 lists abundance values by anatomical element, according to different measures (NISP, MNE, etc.). Appendicular skeleton (NISP 44) outweighs axial bones (NISP 11); MAU\% (Fig. 5) showing peaks at femur, tibia, sacrum and pelvis. A possibility is that, from time to time, hindquarters were consumed whole, and their bones discarded together.

The correlation $r_{s}$ of MAU\% vs. Food Utility Index (FUI) for non-long bones was negative and non-significant $\left(r_{s}-0.25313\right.$, p. 0.48041). Instead, a positive and significant correlation was found for long bones $\left(r_{s}\right.$ 0.88041, p. 0.0206). The same values were obtained for MAU\% vs. marrow cavity volume. These results could reflect differential transport or acquisition of more nutritious elements. As it was noted before, there was a probable ingress of complete primary butchery units, like hindquarters. Being Las Pailas a dense urban settlement, animals should have been killed in the outside, therefore, who owned the herds, and how carcasses were distributed, are other relevant questions. Taking for granted a segmentary society model, it is possible to speculate through a continuum between two extreme situations. In the first scenario, llamas were owned by domestic units composed of nuclear families; on the other hand, herds could have been property of a greater

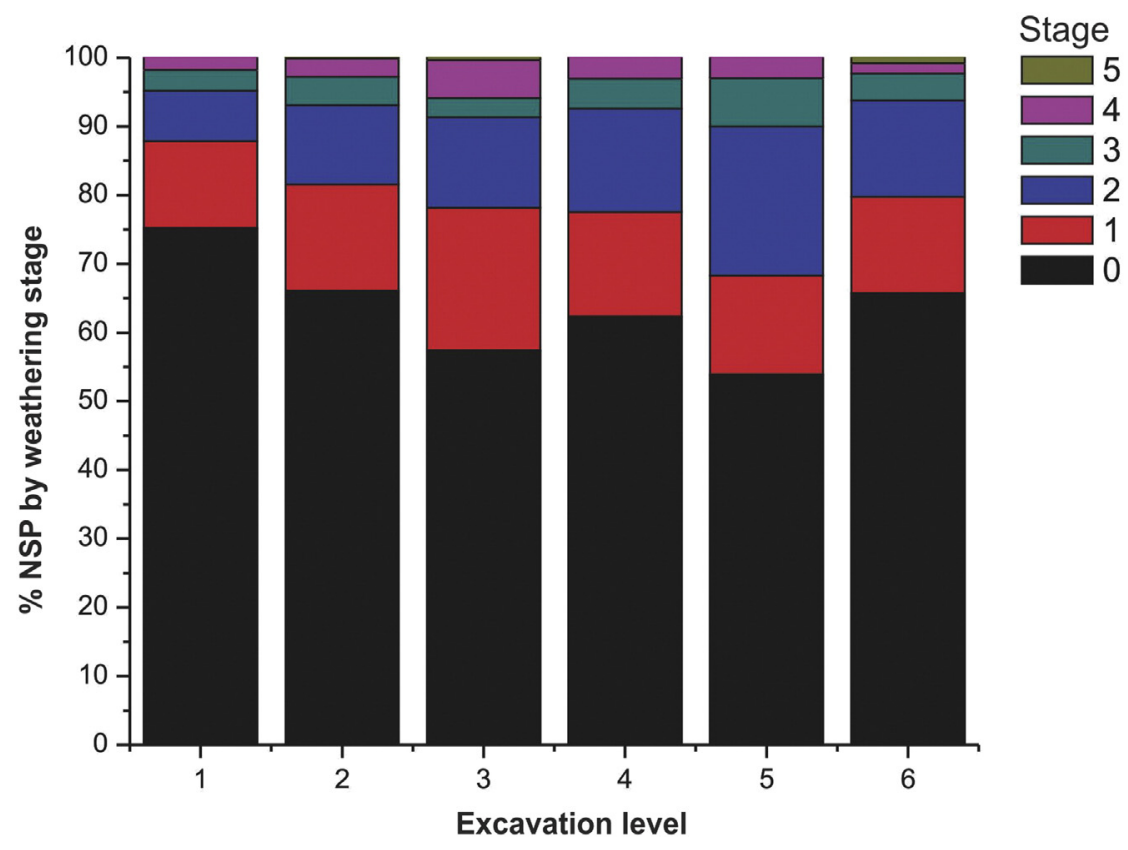

Fig. 7. SSalCac18(1)-TP3, percentage of specimens $\left(\% \mathrm{NSP}_{3-4}\right)$ by weathering stage and level. 
Table 8

SSalCac18(1)-TP 3, natural traces (NSP).

\begin{tabular}{lllll}
\hline \multirow{2}{*}{ Body size class } & \multicolumn{4}{l}{ Natural taphonomic traces (NSP) } \\
\cline { 2 - 5 } & Carnivore & Trampling & Rodents & Roots \\
\hline 2 & 2 & - & 2 & - \\
$2-3$ & - & - & 1 & - \\
3 & 1 & - & - & - \\
$3-4$ & 9 & - & 7 & 2 \\
4 & 26 & 1 & 22 & 7 \\
Total & 38 & 1 & 32 & 9 \\
\hline
\end{tabular}

Table 9

SSalCac18(1)-TP 3, correlation ( $r_{\mathrm{s}}$ ) MAU\% vs. VD $\mathrm{SA}_{\mathrm{SA}}$ for Camelidae sub-assemblage.

\begin{tabular}{lcrl}
\hline Element & Scan-sites & \multicolumn{1}{l}{$\mathrm{r}_{\mathrm{s}}$} & $\mathrm{p} .<0,05$ \\
\hline General & 84 & -0.205511 & 0.060740 \\
Mandible & 8 & 0.552407 & 0.155658 \\
Ribs & 4 & 0.774597 & 0.225403 \\
Scapulae & 4 & -0.316228 & 0.683772 \\
Innominate & 4 & 0.105409 & 0.894591 \\
Humerus & 4 & 0.632456 & 0.367544 \\
Radius-ulna & 6 & -0.376851 & 0.461483 \\
Metacarpal & 4 & -0.632456 & 0.367544 \\
Femur & 5 & 0.948683 & 0.013847 \\
Tibia & 5 & 0.000000 & 1.000000 \\
Calcaneus & 4 & 0.200000 & 0.800000 \\
\hline
\end{tabular}

social segment, e. g. an extended family, or lineage under the rule of one or more deans. In the second scenario, carcasses could have been distributed among domestic units of the same social segment. Data is insufficient to prove any hypothesis, but there are some ethnohistoric references to communal herds at the Bolivian Highland (Murra, 2002), and modern ethnographic accounts of pooling of small herds from related nuclear families for herding and reproduction (Tomka, 1992).

\subsubsection{Fragmentation and fracture patterns}

Except for smaller bones (e. g. basipodia, unfused epiphyses), which are mostly unbroken, most of the assemblage is heavily fragmented (78.18\%, NISP 43) (Fig. 6). Regarding intensity of fragmentation, NISP:MNE ${ }^{2}$ ratio for the sub-assemblage is 1.48 . Tallied by element, the highest values belong to scapulae (NISP:MNE 3.0), mandible (2.0), and radius-ulna (2.0); the remaining elements oscillate between 1.0 and 1.67. Fragmentation of scapulae and mandibles could be accounted by their flat morphology, which makes them more fragile against bending forces (e. g. trampling). For long bones, fragmentation could have been due to marrow and bone grease extraction, pot-sizing (v. Yacobaccio et al., 1998), or bone-tool manufacture.

All of unbroken bones (NISP 12), and 53.49\% (NISP 23) of fragments, are $70 \mathrm{~mm}$ long or less, which is another measurement of fragmentation intensity. Restricting the analysis to long bones, nine specimens showed traits characteristic of green bone break, while another eleven were broken while non-green or fossilized. The mean longitude for fragments green-broken is $71.38 \mathrm{~mm}$ (SD $23.94 \mathrm{~mm}$ ).

\subsubsection{Butchering marks and thermoalteration}

A fragment of distal humerus exhibits transverse and oblique cutmarks on its anterior surface, and could be related to disarticulation. None of the specimens exhibit any trace of thermal modification.

\footnotetext{
${ }^{2}$ It should be noted that for measuring of fragmentation intensity, the NISP:MNE ratio is derived only from broken specimens (cf. Lyman, 1994).
}

Table 10

SSalCac18(1)-TP 3, Camelid specimens counted by age classes and by epiphyseal fusion (NISP) (Age classes: $\mathrm{P}=$ perinatal, $\mathrm{N}=$ neonatal, $\mathrm{Y}=$ young, $\mathrm{I}=$ Immature, $\mathrm{M}=$ Mature. Epiphyseal fusion: $\mathrm{U}=$ unfused, $\mathrm{F}=$ Fused).

\begin{tabular}{ccc}
\hline Epiphyseal fusion & Age class & NISP \\
\hline UF & P-N & 12 \\
& P-Y & 33 \\
F & P-I & 5 \\
& Y-M & 38 \\
& I-M & 57 \\
M & 17 \\
\hline
\end{tabular}

Table 11

SSalCac18(1)-TP 3, anatomical profile for Camelidae.

\begin{tabular}{|c|c|c|c|c|c|c|c|c|c|c|c|c|}
\hline \multirow[b]{2}{*}{ Element } & \multirow[b]{2}{*}{ NISP } & \multicolumn{3}{|c|}{ MNE R } & \multicolumn{3}{|c|}{ MNE L } & \multicolumn{3}{|c|}{ MNE A/0 } & \multirow[b]{2}{*}{ MNEC } & \multirow[b]{2}{*}{ MAU\% } \\
\hline & & $\mathrm{F}$ & UF & 0 & $\mathrm{~F}$ & UF & 0 & $\mathrm{~F}$ & UF & 0 & & \\
\hline Skull & 65 & - & - & - & - & - & - & - & - & 7 & 7 & 87.50 \\
\hline Mandible & 44 & - & - & 9 & - & - & 7 & - & - & - & 16 & 100.00 \\
\hline Hyoid & 1 & - & - & - & - & - & - & - & - & 1 & 1 & 0.00 \\
\hline Loose teeth & 36 & - & - & - & - & - & - & - & - & - & 0 & 0.00 \\
\hline Atlas & 3 & - & - & - & - & - & - & - & - & 2 & 2 & 25.00 \\
\hline Axis & 4 & - & - & - & - & - & - & - & 1 & 1 & 2 & 25.00 \\
\hline Cervical v. & 13 & - & - & - & - & - & - & 1 & 2 & 2 & 5 & 12.50 \\
\hline Thoracic v. & - & - & - & - & - & - & - & - & - & - & 0 & 0.00 \\
\hline Lumbar v. & 2 & - & - & - & - & - & - & - & 2 & - & 2 & 2.08 \\
\hline Sacrum & 1 & - & - & - & - & - & - & 1 & - & - & 1 & 12.50 \\
\hline Caudal v, & - & - & - & - & - & - & - & - & - & - & 0 & 0.00 \\
\hline Sternebrae & - & - & - & - & - & - & - & - & - & - & 0 & 0.00 \\
\hline Ribs & 14 & - & - & 1 & - & - & 1 & - & - & 1 & 3 & 1.56 \\
\hline Scapulae & 25 & 3 & - & - & 3 & 2 & - & - & - & - & 8 & 50.00 \\
\hline Innominate & 19 & - & 1 & 2 & 4 & - & - & - & - & - & 7 & 43.75 \\
\hline Humerus & 35 & 3 & 2 & 1 & 3 & 1 & 1 & - & - & - & 11 & 68.75 \\
\hline Radius-ulna & 61 & 2 & 1 & 5 & 4 & 2 & - & - & - & - & 14 & 87.50 \\
\hline Cuneiform & 5 & - & - & 3 & - & - & 2 & - & - & - & 5 & 31.25 \\
\hline Scaphoid & 2 & - & - & - & - & - & 2 & - & - & - & 2 & 12.50 \\
\hline Lunar & 5 & - & - & 2 & - & - & 3 & - & - & - & 5 & 31.25 \\
\hline Magnum & 2 & - & - & 1 & - & - & 1 & - & - & - & 2 & 12.50 \\
\hline Pisiform & 2 & - & - & 1 & - & - & 1 & - & - & - & 2 & 12.50 \\
\hline Trapezoid & - & - & - & - & - & - & - & - & - & - & 0 & 0.00 \\
\hline Unciform & 3 & - & - & 2 & - & - & 1 & - & - & - & 3 & 18.75 \\
\hline Metacarpal & 13 & - & - & 2 & - & - & 7 & - & - & 2 & 11 & 68.75 \\
\hline Femur & 24 & 1 & - & 3 & 1 & 2 & 2 & - & - & - & 9 & 56.25 \\
\hline Patella & 3 & - & - & - & - & - & - & - & - & 2 & 2 & 12.50 \\
\hline Tibia & 25 & 1 & - & 3 & 5 & 1 & - & - & - & - & 10 & 62.50 \\
\hline Astragalus & 19 & - & - & 5 & - & - & 10 & - & - & - & 15 & 93.75 \\
\hline Calcaneus & 15 & 2 & 1 & 2 & 2 & 2 & - & - & - & - & 9 & 56.25 \\
\hline Cuboid & 4 & - & - & 1 & - & - & 3 & - & - & - & 4 & 25.00 \\
\hline Ectocuneiform & 5 & - & - & 2 & - & - & 3 & - & - & - & 5 & 31.25 \\
\hline Malleolus & 6 & - & - & 4 & - & - & 2 & - & - & - & 6 & 37.50 \\
\hline Navicular & 11 & - & - & 6 & - & - & 3 & - & - & - & 9 & 56.25 \\
\hline Metatarsal & 7 & - & - & 2 & - & - & 1 & - & - & 1 & 4 & 25.00 \\
\hline Metapodia & 104 & - & - & - & - & - & - & 8 & 5 & - & 13 & 40.63 \\
\hline Sesamoids & - & - & - & - & - & - & - & - & - & - & 0 & 0.00 \\
\hline Phalanx 1 & 44 & - & - & - & - & - & - & 15 & 10 & - & 25 & 39.06 \\
\hline Phalanx 2 & 13 & - & - & - & - & - & - & 8 & 2 & 1 & 11 & 17.19 \\
\hline Phalanx 3 & 8 & - & - & - & - & - & - & 3 & - & 4 & 7 & 10.94 \\
\hline
\end{tabular}

\section{Results, part II. SsalCac18 (1), Test Pit 3 - Midden}

\subsection{Overview}

TP 3 is $140 \mathrm{~cm}$ deep, subdivided in seven arbitrary levels of $20 \mathrm{~cm}$. Only the faunal remains from levels $1-6^{3}(0-120 \mathrm{~cm}$ deep) were analyzed, amounting to 4997 specimens. Given their location in the outskirts of the settlement, and the stratigraphic thickness of the midden, it can be

\footnotetext{
3 The Test pit 3 archeofauna was stored at two institutions, the Museo Etnográfico J. B. Ambrosetti and the Instituto de Arqueología (Facultad de Filosofía y Letras, Universidad de Buenos Aires). An exhaustive search was performed, but the archaeofauna of level 7 was not found.
} 


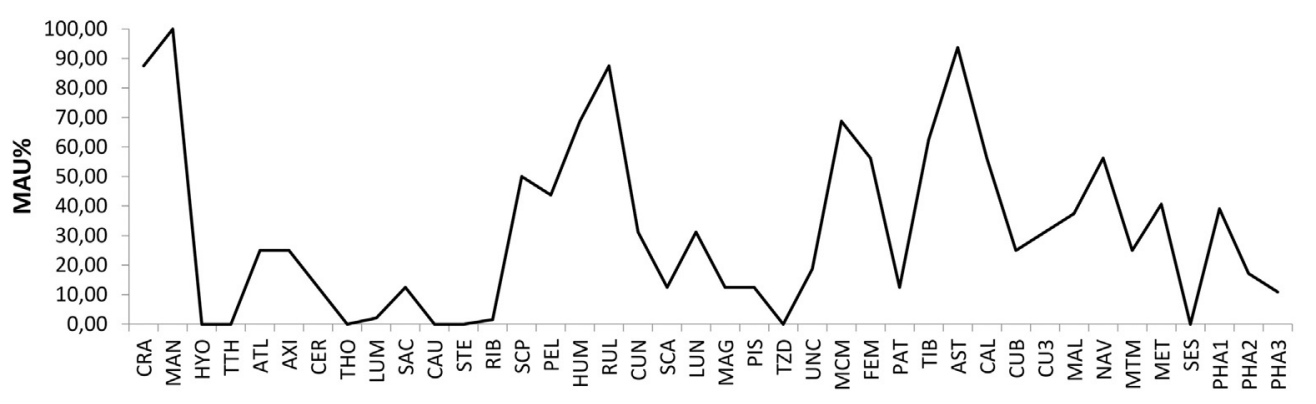

Fig. 8. SSalCac18(1)-TP3, MAU\% for Camelidae.

assumed that this assemblage is an averaged record of subsistence and maintenance activities of various domestic units over an extended time.

As a whole, 1058 specimens were identified taxonomically $(21.17 \%$ of the assemblage) (Table 6). Camelidae is the most frequent taxon (NISP 643) amongst specimens identified in the family rank or better; four morphotypes were recognized: Lama sp., L. glama, Lama guanicoe cacsilensis and V. vicugna vicugna. Other identified taxa were: Canidae (NISP 14), Lagidium sp. (NISP 3), and Homo sapiens (NISP 3).

Of specimens classified in the size classes 3-4, 34.69\% present some sign of weathering. Specimens are distributed in a decreasing order across the six stages of Behrensmeyer (Table 7), suggesting various episodes in a continuous accumulation. Fig. 7 plots the percentage of specimens for each weathering stage and excavation level. Even when all levels show a similar distribution, weathering at intermediate levels had a slightly greater incidence. In terms of taphonomic time, this implies a shorter exposition for bones of first and last levels. It is thus possible that faunal accumulation occurred over a long time, burying quickly the earliest discards and protecting them from weathering agents.

Table 8 summarizes data on natural taphonomic traces, and their incidence is negligible (NSP $80,2.49 \%$ of specimens assigned to any size class). Rodent marks are the most frequent, followed by carnivore gnawing marks. Carnivore marks could have been done by domestic dogs, as there is proof of their presence at Northwestern Argentina before the Regional Developments Period (e. g. La Isla site, at Humahuaca, v. Belotti López de Medina, 2012; also cf. Mengoni Goñalons, 1991a).

\subsection{Camelidae sub-assemblage}

\subsubsection{Density mediated destruction}

A correlation $r_{s}$ analysis of MAU\% vs. VD $\mathrm{SA}_{\mathrm{SA}}$ was conducted over a set of 84 scan-sites, for control of density mediated destruction. The correlation was low and negative, but near to the significance threshold p. $<.05$. The same analysis repeated for single elements with $>3$ scan-sites provided diverse results. In four cases, positive correlations above 0.5 were obtained, but the correlation was significant only for the femur (Table 9). In sum, a density bias could not be discarded entirely, but neither seems to have had a significant nor a homogeneous impact over the assemblage.

5.2.1.1. Minimal number of individuals, taxonomic composition and age profile. A MNI of 10 was derived from the astragalus. Segregating data by epiphyseal fusion, an MNI of two (2) was derived for unfused elements, and a MNI of five (5) for osteologically mature bones. Taking into account identification of specific morphotypes, MNI for fused bones reached a value of six (6): MNI L. glama 3, MNI L. guanicoe cacsilensis 1 , and MNI $V$. vicugna vicugna 2.

Table 10 plots the age profile derived from NISP for TP3. A $27.77 \%$ of the specimens (NISP 45) belong to animals culled before they were two years old. Of these, 12 specimens come from perinatal or neonatal animals. Another $45 \%$ of specimens are in the immature to mature range (NISP 74), including 17 specimens coming from animals well over three years old. The ratio of unfused:fused specimens is low, whether be it derived from NISP (50:112) or MNI (2:6). This profile could indicate the predominance of secondary exploitation (Kuznar, 1990; Yacobaccio et al., 1998).

\subsubsection{Anatomic profile}

Abundance and relative frequency of anatomical elements is listed in Table 11, while MAU\% values are plotted in Fig. 8. Excluding mandible and crania, the greatest abundance of elements belong to the appendicular skeleton. Among long bones, distal limbs (radius-ulna and tibia) are the most frequent. In the lab, two groups of basipodia belonging to individual limbs were identified. The first one comes from a left hindlimb of Lama sp. (MNI 1); the second one is from a forelimb of L. glama (MNI 1). Discarding of articulated basipodia suggests that they were carried as riders, elements of low value attached to others of greater economic return (v. Binford, 1978).

Spearman correlation of MAU\% vs. FUI for non-long bones is negative and non-significant $\left(r_{s}-0.59575, p .0 .06916\right)$, while for long bones is positive and non-significant $\left(r_{s} 0.16217\right.$, p. 0.7283). This apparent contradiction could be due to an inverse relation between structural density and FUI (cf. Marean and Frey, 1997). It should be remembered

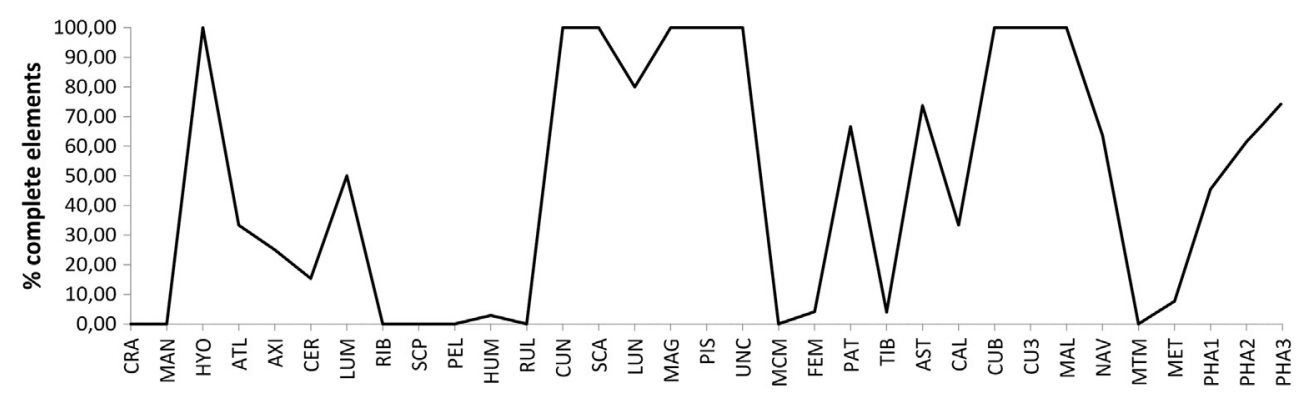

Fig. 9. SSalCac18(1)-TP3, percentage of complete bones by anatomical element (Camelidae). 
that both mandible and ribs showed positive results for density mediated destruction. Correlation of MAU\% vs. marrow cavity volume is positive and non-significant ( $r_{s} 0.42857$, p. 0.3965).

\subsubsection{Fragmentation}

Only $20.37 \%$ (NISP 131 ) of the sub-assemblage is constituted by unbroken bones, mostly vertebrae, phalanxes, basipodia, unfused epiphysis and other small elements (Fig. 9). Remaining specimens are heavily fragmented, with a global NISP:MNE ratio of 3.49; the highest ratios by element are from crania, metapodia, ribs and radius-ulna (Table 12). A 64.65\% of broken bones (NISP 331) is less than $60 \mathrm{~mm}$ long.

Fracture morphology for 211 fragments of long bones was characterized. Breakage of non-green bones, or with columnar fracture edges, accounts for $64.45 \%$ of specimens, and green broken bones for the remaining $35.55 \%$ (NISP 75) (Table 13). The mean length for green broken bones is $62.3 \mathrm{~mm}$ (SD $24.9 \mathrm{~mm}$ ). Impact marks -flake scars, notches- are more frequent on green bones (Table 14), suggesting intentional breakage (marrow and grease extraction, pot-sizing).

\subsubsection{Butchering marks}

Fig. 10 shows the location and frequency (NISP) of butchering marks. A detailed description of these marks is given in the upcoming paragraphs, followed by their interpretation according to field observations by Binford (1981, 96-142)

Mandible: four specimens exhibit cut-marks on the lateral surface of the ramus, and over the caudolateral surface of the dentary. Two specimens show scraping-marks at the lateral surface of the ramus. Some of these marks resemble M- 2 and M- 6 cuts described by Binford (1981 109, 136), both related to disarticulation.

Axis: two specimens show transversal and longitudinal marks over the lateral and dorsal surfaces of the vertebra, near the atlas-axis joint. They could have been produced during removal of the skull.

Ribs: two specimens with scraping marks, one of them near the thoracic vertebrae.

Scapulae: four specimens with cut-marks, and one with scraping marks. Their orientation ranges from longitudinal, to oblique, and transverse to the proximodistal axis, across both surfaces of the blade, and over the glenoid cavity. Together, these marks are similar

Table 12

SSalCac18(1)-TP3, NISP:MNE for fragmented bones of Camelidae sub-assemblage.

\begin{tabular}{|c|c|c|c|}
\hline Element & NISP & MNE & NISP:MNE \\
\hline Skull & 65 & 7 & 9.29 \\
\hline Mandible & 44 & 16 & 2.75 \\
\hline Atlas & 2 & 1 & 2.00 \\
\hline Axis & 3 & 1 & 3.00 \\
\hline Cervical v. & 11 & 3 & 3.67 \\
\hline Lumbar v. & 1 & 1 & 1.00 \\
\hline Sacrum & 1 & 1 & 1.00 \\
\hline Ribs & 14 & 3 & 4.67 \\
\hline Scapulae & 25 & 8 & 3.13 \\
\hline Innominate & 19 & 7 & 2.71 \\
\hline Humerus & 34 & 11 & 3.09 \\
\hline Radius-ulna & 61 & 14 & 4.36 \\
\hline Lunar & 1 & 1 & 1.00 \\
\hline Metacarpal & 13 & 11 & 1.18 \\
\hline Femur & 23 & 9 & 2.56 \\
\hline Patella & 1 & 1 & 1.00 \\
\hline Tibia & 24 & 9 & 2.67 \\
\hline Astragalus & 5 & 1 & 5.00 \\
\hline Calcaneus & 10 & 4 & 2.50 \\
\hline Navicular & 4 & 2 & 2.00 \\
\hline Metatarsal & 7 & 4 & 1.75 \\
\hline Metapodia & 96 & 13 & 7.38 \\
\hline Phalanx 1 & 24 & 11 & 2.18 \\
\hline Phalanx 2 & 5 & 2 & 2.50 \\
\hline Phalanx 3 & 2 & 1 & 2.00 \\
\hline Global & 495 & 142 & 3.49 \\
\hline
\end{tabular}

to S-2, S-3 and S-4 (Binford, 1981 121-122, 140), produced during dismembering and filleting.

Humerus: two fragments have cut-marks over the distal diaphysis, on the medial and anterolateral surfaces respectively. The second mark could be assimilated to Hd-5 (Binford, 1981 121-124, 141) (disarticulation). A sole diaphysis fragment shows a percussion pit.

Radius-ulna: five specimens exhibit transverse and oblique cut-marks, on the proximal and distal diaphysis. Given orientation and location, they are likely product of dismembering. Scraping is recorded for one specimen, located on its lateral diaphysis. Four fragments show percussion grooves and pits.

Carpal bones: a transversal cut-mark over a scaphoid, likely from dismembering.

Metacarpals: two specimens with chopping marks over the diaphysis.

Femur: two specimens with cut-marks located at the proximal and middle diaphysis, respectively. The first fragment also presents chopping-marks. Cut-marks of this specimen could be analogous to Fp-9 (Binford, 1981, 138), from filleting.

Tibia: two specimens with oblique cut-marks over the proximal diaphysis. One of these specimens also exhibits scraping marks. Another diaphysis exhibits a percussion pit.

Calcaneus: oblique cut-marks, maybe product of filleting. Another fragment has chopping-marks on the anterolateral plane, over an articular surface.

\subsubsection{Thermoalteration}

Only 58 specimens suffered any degree of thermal alteration (Table 15). Seven of them exhibit supplementary surface modifications (exfoliations, crackling).

\subsubsection{Functional pathologies}

A phalanx of Lama sp. shows signs of exostosis on the anterior diaphysis. This bone could have belonged to a cargo animal (a llama) (cf. Izeta and Cortés, 2006).

\subsection{Non-Camelidae families sub-assemblage}

This sub-assemblage refers to all specimens identified also in the Family rank, but belonging to other taxa (NISP 33) (Table 6).

Homo sapiens: It is somewhat intriguing the presence of human bones at a midden. These specimens are a near-complete mandible, a bulla tympanica and a loose incisive tooth; none exhibit cultural traces. A reasonable hypothesis is that they could have come from a tomb disturbed by settlement expansion or remodeling.

Hippocamelus antisensis (Cervidae): this taxon reaches a MNI of one, and, excepting for a metapodial fragment, all specimens come from

Table 13

SSalCac18(1)-TP 3, fracture morphology for long bones diaphyses (NISP). (G: green, N: non-green, C: columnar).

\begin{tabular}{|c|c|c|c|c|c|c|c|c|c|c|}
\hline \multirow{2}{*}{ Element } & \multicolumn{3}{|c|}{ Spiral } & \multicolumn{3}{|c|}{ Longitudinal } & \multirow{2}{*}{$\begin{array}{l}\text { Transversal } \\
\text { simple } \\
\mathrm{N}\end{array}$} & \multicolumn{3}{|c|}{$\begin{array}{l}\text { Transversal } \\
\text { jagged }\end{array}$} \\
\hline & G & $\mathrm{N}$ & C & G & $\mathrm{N}$ & C & & G & $\mathrm{N}$ & C \\
\hline Scapulae & - & 2 & - & - & 1 & - & - & - & - & - \\
\hline Humerus & 15 & 5 & 1 & 1 & 1 & - & - & - & 1 & - \\
\hline Radius-ulna & 8 & 7 & 2 & 3 & 22 & 2 & - & - & 1 & 1 \\
\hline Metacarpal & 1 & 2 & 2 & 1 & 3 & - & - & - & 1 & - \\
\hline Femur & 5 & 5 & - & 2 & 8 & - & - & - & - & - \\
\hline Tibia & 7 & 4 & - & - & 3 & - & - & - & - & - \\
\hline Calcaneus & - & 1 & - & - & 5 & - & - & - & - & - \\
\hline Metatarsal & - & 2 & - & - & 1 & 1 & - & - & 1 & - \\
\hline Metapodia & 18 & 5 & - & 6 & 29 & - & 1 & 1 & 1 & - \\
\hline Phalanx 1 & 3 & 3 & 1 & 3 & 7 & - & - & 1 & 1 & - \\
\hline Phalanx 2 & - & 2 & - & - & 1 & - & - & - & - & - \\
\hline Totals & 57 & 38 & 6 & 16 & 81 & 3 & 1 & 2 & 6 & 1 \\
\hline
\end{tabular}


Table 14

SSalCac18(1)-TP3, impact marks associated to fracture borders (NISP).

\begin{tabular}{lll}
\hline Borde de fractura & Impact marks (NISP) & \\
\cline { 2 - 3 } & Flake scars & Notches \\
\hline Green & 6 & 4 \\
Non-green & 2 & 1 \\
Total & 8 & 5 \\
\hline
\end{tabular}

levels five and six. Therefore, it is possible that all bones belonged to a single animal. Identified elements are mandible, forelimb (humerus, radio and basipodia), pelvis and metapodia. The humerus was fractured when still green, the edge is spiral and the bone shows a chopping mark.

$H$. antisensis or taruca was a rare game, and its remains from other agropastoralist sites are usually very scarce, often amounting only to fragments of antler or a few loose phalanxes. An explanation could be a low probability of encounter, at least in comparison to wild camelids. Extrapolating data from the southern huemul (Hippocamelus bisulcus), cervids of this genre are solitary or join small family groups (De Nigris, 2004), of two or three individuals at most, which couples with a low demographic density.

Canidae: fourteen specimens. Discounting a humerus, all specimens belong to the head (crania, mandible, and loose teeth). An MNI of three was derived from the right hemi-mandible. All belong to small animals; one hypothesis is that they belong to domestic dogs, which were identified in a previous analysis by Mengoni Goñalons (1991a). These bones do not show any taphonomic trace.

Lagidium sp. (Chinchillidae): Three specimens (radius NISP 1, pelvis NISP 2).

Chaetophractus vellerosus (Dasypodidae): an unfused diaphysis of humerus, two right femora with complete epiphyseal fusion, and a dermic plate. Two specimens exhibits punctures by carnivores.
Table 15

SSalCac18(1)-TP3, NISP by thermal alteration stage. (0: unmodified, 1: burnt, 2: carbonized, 3: calcinated).

\begin{tabular}{lr}
\hline Color & NISP \\
\hline 0 & 585 \\
1 & 55 \\
2 & 2 \\
3 & 1 \\
\hline
\end{tabular}

\section{Discussion}

As seen in the review section, current zooarchaeological research for Northwestern Argentina sustains the existence of a pastoralist strategy, with a subordinated hunting component, for ca. 1000 BC - AD 1500 Period. These activities were specialized on different species of Lamini (specialization was total for herding, as llama was the only domestic ungulate), and their importance relative to agriculture was variable along different ecological zones. Also, there is some evidence of geographic and diachronic non-random variance of the zooarchaeological record, especially of age-profiles, and of domestic to wild ratios, for the sub-dataset of Camelidae. Yet, there are still many and large gaps in the record, and a great deal of averaging in the few extant attempts at regional syntheses. The results published here are part of an ongoing research project, whose goal is to produce relevant zooarchaeological data for Las Pailas locality and the Calchaquí Valley, and to inquire on the economic practices through the Formative and Regional Developments periods at the valley.

If yet too early for providing any definite conclusion for the Calchaquí Valley as a whole, the data from TP3 and S2 is informative of some aspects of subsistence, and of faunal resources management

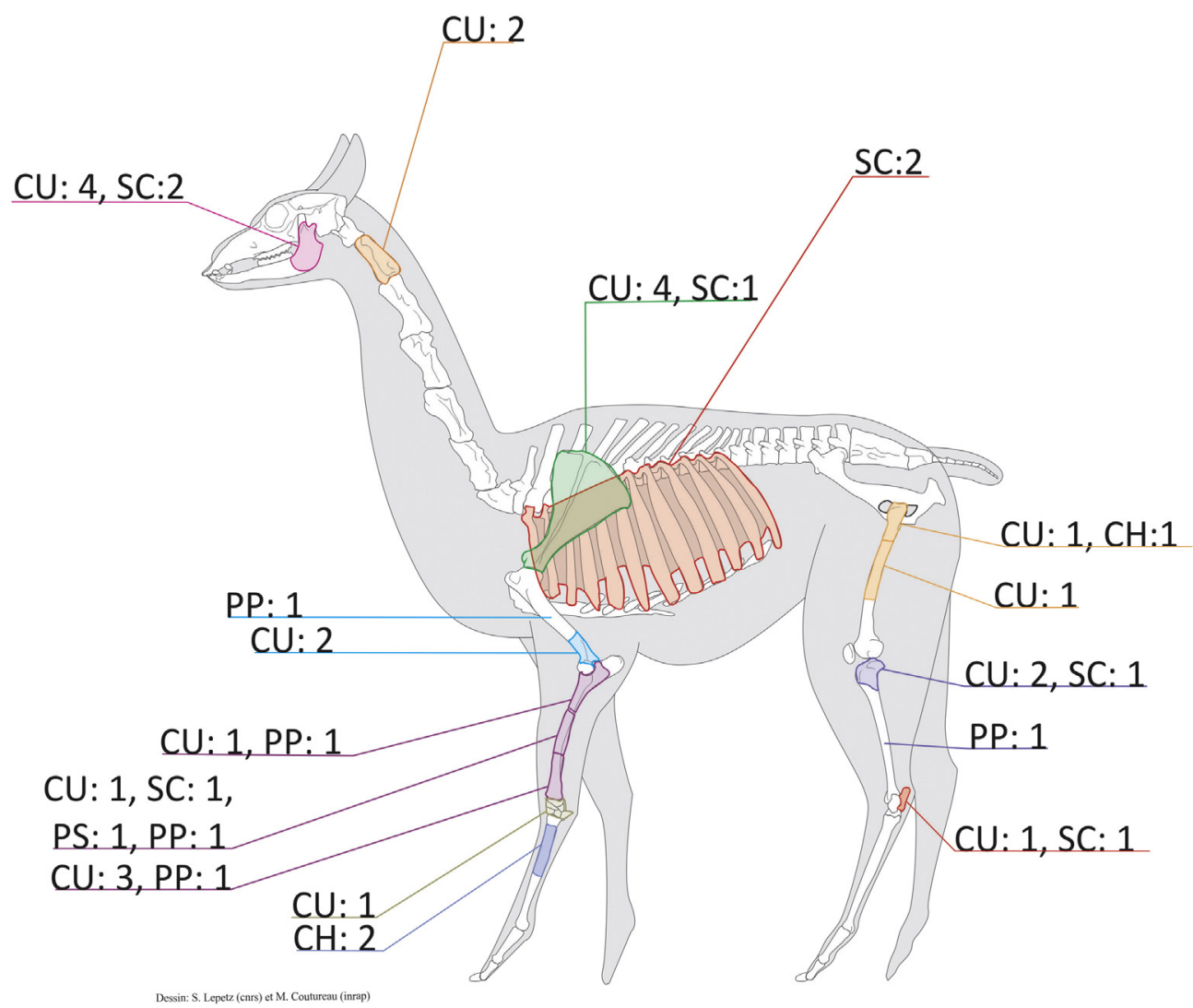

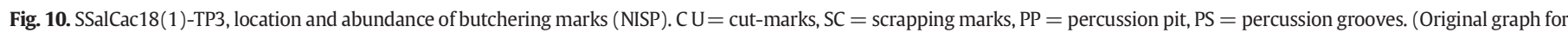
L. guanicoe by M. Coutureau et al. Source: Corpus of digitalized mammal skeletons. URL: http://www.archeozoo.org ) 
at Las Pailas. A general and predictable pattern is the overall predominance of $L$. glama, followed by $L$. guanicoe, and $V$. vicugna. That fits well with previous research for the Northwest. But some other variables, like age-profiles, taxonomic diversity, and anatomic profiles, are quite dissimilar between TP3 and S2. It is tempting to disregard these differences as a sample error, as S2 is a smaller assemblage, but that could be a mistake (a type II error).

Urban settlement of complex societies are characterized by the concurrence of many taphonomic histories, as agents are constrained by factors ranging from differential access to staple foods, to overcrowding and uncleanliness. From location, assemblage size, and stratigraphic thickness, it is suggested that TP3 and S2 represent different accumulation times and contributions of a variable number of agents. If so, each allows to glimpse at different facets of economic practices.

The often fragmentary and imprecise nature of archaeological evidence usually blurs the difference between normal values of a social system for a segment of its trajectory, the variance of actual practices that produces these values, and the goals, pragmatic knowledge, structural and casual constraints of these practices. Ethnographic research on modern Puna pastoralists highlights the flexibility and short-term forecast of their economic choices, as they must cope with high levels of risk and uncertainty (Göbel, 1994). Also, it is worth mentioning the blend of pragmatic knowledge and cosmology in their ethnozoology. Llamas, guanacos, and vicuñas are simultaneously conceived as heterogeneous and homologous: guanaco and vicuña are salka (wild), while the llama is uywa (domestic). At the same time, they are all indigenous species (contrasting with sheep, for example), and vicuñas are reputed as the herds of deities like Coquena (Vilá, 2012, 2014). Second, risk is acknowledged symbolically as rites like the challada are performed prior to culling an animal, to thank mother earth and propitiate the reproduction of the herds (Yacobaccio and Malmierca, 2006).

There is no need for direct ethnographic analogy, even when wellgrounded on historical links, to suppose that past peoples conducted themselves through similar pragmatic criteria, made of traditional knowledge, myths, emic categories and individual experience, which they adapted to contingent conditions. A taphonomic multiscalar approach could be a strategy suited to explore the relationship between tactics, structuration and long-term evolution of economic subsystems. In the following paragraphs the intra-site variability of Las Pailas archaeofaunas as well as the regional and temporal variability of the zooarchaeological record for the central and northern Calchaquí Valley is discussed.

Both analyzed assemblages show predominance of Camelidae over other families, and of L. glama over wild camelid species. But, on a finer grained analysis, their taxonomic diversity differs considerably. Only one family was identified at S2; while at TP3 there were at least five families identified besides camelids (remains of Cervidae, Canidae, Lagidium sp., Chaetophractus, H. Sapiens). The reduced richness of S2 is probably linked to the assemblage volume (NISP), i.e. a sampling error. Yet this sampling difference is also the outcome of a shorter series of subsistence activities, coming from one, or a few at most, domestic units. On the other hand, Test Pit 3 should mirror the maximum diet breadth of an ample set of residential units over a long time-span.

Taxonomic diversity of the Camelidae sub-assemblages varies too. L. glama accounts for the $83 \%$ of every specimen assigned to any specific morphotype at S2, while it reaches a 57\% at TP3. Moreover, specimens of L. guanicoe cacsilensis were identified at TP3, but are completely absent from S2. Again, we could be facing a sampling error. If camelid taxa from TP3 are ranked according to their NISP values, it can be observed that: 1) the least abundant (L.guanicoe cacsilensis) is precisely the one lacking from S2; 2) the ratio of the second least abundant at TP3 ( $V$. vicugna vicugna), is slightly lower at $\mathrm{S} 2$. It should be noted that there is some metric overlap between smaller llamas and L. guanicoe cacsilensis, and that specimens identified as Lama sp. could belong to any of the two species. If the NISP values of Lama sp., L. guanicoe cacsilensis and
L. glama are added, the relative abundance of $V$. vicugna vicugna against big camelids is similar among assemblages (S2 14\%, TP3 21\%).

As for why northwestern pastoralists kept hunting, there are three main hypothesis. First, that vicuñas were captured for shearing, as its wool was (and still is) highly valued. This practice (chaku) could be traced historically to the Inka rule at least, as vicuña wool was used for production of fine textiles of great political and symbolic meaning (Murra, 2002; Vilá, 2012). Other hypothesis is that guanaco and vicuña could have been hunted for incorporation to llama herds, and for hybridization (Mengoni Goñalons, 1991a; Wing, 1975). But the most accepted hypothesis, especially for the semidesertic Puna or Highland, is that hunting was a strategy for conservation of domestic herds and risk-aversion (Escola, 2002; Yacobaccio et al., 1997-1998). The same consideration could be extended to lower valleys, like Calchaquí. Pre-Hispanic herding at Northwestern Argentina was monospecific, and herds of llama are vulnerable to yearly fluctuations in their reproduction and size, caused by diseases, predators, droughts, etc. (Göbel, 1994; Sotomayor Berrío, 1984). Hunting made it easier for pastoralists to maintain or grow their herds (Escola, 2002). Another factor was secondary exploitation, which favored conservation of domestic animals (e. g. castrated males for caravans) (Izeta, 2007).

Age-profiles are notoriously different. TP3 camelid age profile shows dominance of fused bones (69\% NISP, 75\% MNI); S2 instead, shows lower ratios (56\% NISP, $50 \% \mathrm{MNI}$ ). The former profile is akin to secondary production and selection of old animals for culling; while S2 could represent a mixed strategy, killing more young animals for meat. Finally, anatomic profile for S2 showed a positive correlation between MAU\% and FUI for long bones, pointing to a preferential transport or acquisition of high-yielding elements, while the profile of TP3 approximates an unbiased pattern. This seems coherent with the hypothesis of a more averaged record for TP3. On the other hand, higher frequencies of young animals and meatier body parts at $\mathrm{S} 2$ could be indicative of differential access to faunal resources.

As analysis is broaden to the central and northern Calchaquí Valley, so does variability among assemblages. The evidence is scarce (ex supra), consisting in reports for Campo Colorado - SsalLap2 (Formative), and Molinos I (Regional Developments) (de Guerrero, 1968; Izeta et al., 2009b). To compare these assemblages with our own research, different measures of taxonomic diversity were used (NTaxa, V', based on NISP by taxonomic family). Percentage of specimens identified as L. glama (\%NISP DC) over the sum of specimens of Camelidae identified in the species rank, and percentage of unfused bones of Camelidae over the sum of unfused and fused specimens, were calculated too.

At first sight, taxonomic richness and diversity does not exhibit any variation between Formative and Regional Developments periods (Table 16), but data of the former period comes from a single site (SSalLap2). As expected, Camelidae is predominant at every assemblage. Regarding the interspecific diversity of Camelidae, there is data only for the Regional Developments; domestic animals (L. glama) are dominant at Las Pailas (Table 16), but completely lacking at Molinos 1.

As for the age-profile of Camelidae (Table 17), there is a greater abundance of perinatal and young animals at Campo Colorado. With regard to this site and other contemporaneous from Northwestern Argentina, Olivera (1997) postulated that an overrepresentation of

Table 16

Taxonomic richness and diversity for agro-potter faunal assemblages from central and northern Calchaquí Valley (RD: Regional Developments).

\begin{tabular}{lcrclll}
\hline Site & Period & NISP & NTaxa & H' $^{\prime}$ & V' $^{\prime}$ & \%NISP DC \\
\hline SSalLap2 & Formative & 458 & 3 & 0.193985 & 0.176572 & - \\
SSalCac18(1) S2 & RD & 55 & 1 & 0.00 & - & 83.33 \\
SSalCac18(1) TP3 & RD & 676 & 6 & 0.263841 & 0.147253 & 56.67 \\
Molinos I R & RD & 318 & 4 & 0.1233 & 0.088942 & - \\
Molinos I R1 +2 & RD & 48 & 1 & 0.00 & - & 0.00 \\
\hline
\end{tabular}


Table 17

NISP and MNI for unfused (UF) and fused (F) bones of Camelidae.

\begin{tabular}{|c|c|c|c|c|c|c|}
\hline \multirow[b]{2}{*}{ Site } & \multicolumn{2}{|l|}{ NISP } & \multicolumn{2}{|c|}{ MNI } & \multicolumn{2}{|l|}{$\%$ UF } \\
\hline & UF & $\mathrm{F}$ & UF & $\mathrm{F}$ & NISP & MNI \\
\hline SSalLap2 & 373 & 50 & - & - & 88 & - \\
\hline SSalCac18(1)S2 & 12 & 15 & 2 & 2 & 44 & 50 \\
\hline SSalCac18(1)TP3 & 50 & 112 & 2 & 6 & 31 & 25 \\
\hline Molinos I R1 + R2 & - & - & 1 & 2 & 25 & 33 \\
\hline Molinos I R & - & - & - & - & 20 & - \\
\hline
\end{tabular}

young animals could be a product of selective culling to avoid degradation of pastures. For the Regional Developments, the MNI-based ratio of unfused bones for Molinos $1 \mathrm{R}$ and R1-R2 is similar to TP3, highlighting the greater frequency of young-immature animals at S2.

On a bigger scale, zooarchaeological record of the Calchaquí Valley is broadly similar to that of the southern valleys of the Calchaquí Area (Yocavil, Cajón, western slopes of Aconquija mountains). Both areas show a dominance of Camelidae. Also, they share a greater ratio of young camelids in the earliest assemblages (at the beginning of the Formative Period). On the other hand, while Yocavil shows an increase of taxonomical evenness since the Formative Period, mainly due to micro- and meso-fauna, Regional Developments assemblages from central and northern Calchaquí Valley are less even than SSalLap2 (Formative). Also, Regional Developments assemblages of Calchaquí are less even (V' 0.09-0.18) than those of Yocavil valley for the same period (V'0.32-0.37) (Belotti López de Medina, 2015). The broadening of taxonomic diversity for the Yocavil Valley has been interpreted as a complementary strategy of herd conservation for secondary exploitation (Izeta, 2007), and as a kind of intensification promoted by differential control of surplus in chiefdom-like polities (Belotti López de Medina, 2015). The less diverse assemblages observed in the Calchaquí Valley could thus be indicative of differences in the management of faunal resources, or of different social stressors over the force and means of production of households. Nonetheless, faunal evidence for the Calchaquí Valley remains scarce, and any hypothesis about long-term and intervalley variance of the zooarchaeological record remain speculative for the time being.

\section{Conclusions}

Evidence from Las Pailas and other Calchaquí sites tends to conform major trends documented at other valleys. First, a monospecific pastoralist system based on L. glama, largely complemented by specialized hunting of guanaco and vicuña; second, a relative increase in culling of old animals from Formative to Regional Developments Period. Focusing on inter- and intra-site variability at the central-north Calchaquí Valley, Camelid sub-assemblages seem to vary on three critical variables: taxonomic diversity, age-profiles, and anatomic profiles.

According to its location and size, the biggest assemblage, SSalCac18(1)-TP3, has been interpreted as an open dump, used for waste-disposal by many individuals, for a considerable amount of time. This assemblage shows the greatest taxonomic diversity (maximum diet breadth, maybe), and unbiased selection of anatomical elements for Camelidae. The age-profile of Camelidae points to conservation of animals and secondary exploitation. It is proposed these results could be a proxy of normal (average) values of the pastoralist system at Las Pailas.

The second assemblage (S2) is far less diverse taxonomically, as only one family, and two species, were identified. This is to be expected, as a smaller assemblage probably carries a sampling error, missing unusual/ secondary food staples. S2 also shows a greater ratio of youngimmature camelids, and some amount of selection of meaty body elements. These patterns could be random, but their divergence from TP3 is big enough as to suspect selection towards quantity and quality of meat. This could be related to social complexity, or special occasions, but is also indicative of the variability of actual choices in relation to normal values. Nevertheless, more data is necessary to fully understand variability at Las Pailas. Currently, both the remaining assemblages from 1972-1973, and those of recent excavations by other research groups, are being analyzed and the results will be published in a near future.

Finally, Molinos I R1-2 is the smallest of the reviewed assemblages, and the only one dominated exclusively by wild camelids. It is a small sample from a residential compound, and hardly represents their normal diet. Nonetheless, it illustrates the punctual variations of economic activities against averaged values on a bigger scale. At present, there are various research groups working along the Calchaquí Valley, so is reasonable to expect new zooarchaeological data for other sites besides Las Pailas in the upcoming years. In this way, it will be possible to construct a more detailed picture of exploitation of faunal resources along the Formative, Regional Developments and Inka periods for the valley, of its evolution, intra-valley and inter-valley variability.

\section{Acknowledgements}

Las Pailas assemblages were analyzed as part of my doctoral research, with grants from the Agencia Nacional de Promoción Científica y Tecnológica, Universidad de Buenos Aires y el Consejo Nacional de Investigaciones Científicas y técnicas. The research was carried out at Proyecto arqueológico Yocavil (Museo Etnogrático J. B. Ambrosetti, FFy-UBA), with funding from the following grants UBACyT F-152, F029 y 20020100100632, CONICET PIP 6148 y 11220090100311 , FONCYT PICT 12163, 34511 y 0113. Identification of bone specimens took place at the Instituto de Arqueología (FFyL-UBA)

I thank my advisors, Luis González and Andrés Izeta. Also, I would like to thank Myriam Tarragó, for her advice and for trusting me with the reanalysis of the faunal remains from Las Pailas. I also wish to thank Guillermo Mengoni Goñalons and to the Instituto de Arqueología (FFyL-UBA), to Leticia Cortés and Eliana Steinberg.

\section{References}

Acuto, F.A., 2007. Fragmentación vs. integración comunal: Repensando el Período Tardío de Noroeste Argentino. Estudios Atacameños: Arqueología y Antropología Surandinas 34 pp. 71-95

Acuto, F.A., Kergaravat, M., Amuedo, C., 2011. Experiencias de la muerte y la representación de las personas en las prácticas funerarias del Valle Calchaquí norte. Comechingonia 14, 23-54.

Albeck, M.E., 2000. La vida agraria en los Andes del Sur. In: Tarragó, M.N. (Ed.), Los pueblos originarios y la conquista. Sudamericana, Buenos Aires, pp. 187-228.

Baldini, L., 2003. Proyecto arqueología del valle calchaquí central (Salta, Argentina): síntesis y perspectivas. An. N.E. 6, 219-239.

Baldini, L., Baffi, E.I., Quiroga, L., Villamayor, V., 2004. Los Desarrollos Regionales en el Valle Calchaquí Central, Salta. Relac. Soc. Argent. Antropol. 29, 59-80.

Belotti López de Medina, C.R., 2010. Una primera aproximación al desarrollo del modo de producción tribal y la evolución del registro zooarqueológico en el sur de los valles Calchaquíes (Catamarca). In: Gutierrez, M.A., De Nigris, M., Fernández, P.M., Giardina, M., Gil, A., Izeta, A.D., Neme, G., Yacobaccio, H. (Eds.), Zooarqueología a principios de siglo XXI. Aportes teóricos, metodológicos y casos de estudio. Ediciones del Espinillo, Buenos Aires, pp. 189-198.

Belotti López de Medina, C.R., 2011. Zooarqueología del sitio formativo Soria 2, valle de Yocavil (Catamarca), siglo I d.C. Rev. Museo Antropol. 4, 3-16.

Belotti López de Medina, C.R., 2012. En compañía de los muertos. Ofrendas de animales en los cementerios de La Isla (Tilcara, Jujuy). Intersecciones en Antropología 13, pp. 345-357.

Belotti López de Medina, C.R., 2015. Desigualdad e intensificación de la subsistencia en el valle de Yocavil (Catamarca y Tucumán, Argentina) entre los siglos I a.C y XVI d.C. Relac. Soc. Argent. Antropol. 40, 73-100.

Behrensmeyer, A.K., 1978. Taphonomic and ecologic information from bone weathering Paleobiology 1, 150-162.

Benavente, M.A., Adaro, L., Gecele, P., Cunazza, C., 1993. Contribución a la determinación de especies animales en arqueología: familia camelidae y taruca del norte. Universidad de Chile, Vicerrectoría académica y estudiantil, Departamento Técnico de Investigación, Santiago.

Binford, L.R., 1978. Nunamiut ethnoarchaeology. Academic Press, New York.

Binford, L.R., 1981. Bones: ancient men and modern myths. Academic Press, New York. Binford, L.R., 1984. Faunal Remains from Klasies River Mouth. Academic Press, Orlando.

Burger, R.L., Salazar, L.C., 2003. The 1912 Yale Peruvian Scientific Expedition Collections from Machu Picchu: Human and Animal Remains. Yale University Press.

Burkart, R., Bárbaro, N.O., Sánchez, R.O., Gómez, D.A., 1999. Eco-Regiones de la Argentina. Programa Desarrollo Institucional Ambiental, Administración de Parques Nacionales, Buenos Aires. 
Carbonelli, J.P., 2014. Obsidianas y puntas de proyectil: sustancia y forma de las relaciones sociales en Las Pailas, Catamarca, Argentina. Rev. Colomb. Antropol. $50,117-137$.

Cohen, A., Serjeantson, D., 1996. A manual for the identification of Bird Bones from archaeological sites. revised edition. Archetype Publications, London.

Chaix, L., Méniel, P., 2005. Manual de arqueozoología. Ariel, Barcelona.

Chaplin, R.E., 1971. The Study of Bones from Archaeological Sites. Academic Press, New York

de Guerrero, L.R., 1968. Análisis: restos óseos de animales - SSalLap2.

DeMarrais, E., 2001. La arqueología del norte del valle Calchaquí. In: Berberian, E., Nielsen, A.E. (Eds.), Historia Argentina Prehispánica. Editorial Brujas, Córdoba, pp. 289-346.

DeMarrais, E., 2013. Undestanding Heterarchy: Crafting and Social Projects in Pre-Hispanic Northwest Argentina. Cambridge Archaeological Journal 23, 345-362.

Dillehay, T.S., Nuñez Atencio, L., 1988. Camelids, Caravans and Complex Societies in the Soth-Central Andes, Recent Studies in Pre-Columbian Archaeology. BAR International Series 421. John and Erica Hedges Ltd, Oxford.

De Nigris, M., 2004. El consumo en grupos cazadores recolectores. Un ejemplo zooarqueológico de Patagonia meridional Sociedad Argentina de Antropología, Buenos Aires.

Elkin, D., 1996. Arqueozoología de Quebrada Seca 3: indicadores de subsistencia humana temprana en la Puna Meridional Argentina. Universidad de Buenos Aires, Buenos Aires.

Escola, P.S., 2002. Caza y pastoralismo: un reaseguro para la subsistencia. Relac. Soc. Argent. Antropol. 27, 233-245.

Fernández Varela, V., Peña, M.J., De Aguirre, M.J., 2001. Zooarqueología de sitios pastoriles del NOA entre ca. 1500 a 800 años AP. Actas del XIII Congreso Nacional de Arqueología Argentina. Imprenta de la FFYH-UNC, Córdoba.

Flores Ochoa, J.A., 1975. Pastores de Alpacas. Allpanchis 8, 5-23.

Galotta, D.R., Galotta, J.M., 1988. Osteología del llama (Llama glama guanicoe f. d. glama Linnaeus, 1978). Rev. Cienc. Agrar. Tecnol. Aliment. 9, 19-61.

Gamarnik, L.C., 2009. Análisis cerámico de una unidad habitacional de Las Pailas, valles Calchaquíes, provincia de Salta. Facultad de Filosofía y Letras, Universidad de Buenos Aires, Buenos Aires.

Gluzman, G., 2008. Producción metalúrgica de bienes utilitarios en el noroeste argentino prehispánico. In: Tarragó, M.N., González, L.R. (Eds.), Estudios arqueológicos en Yocavil. Asociación Amigos del Museo Etnográfico, Buenos Aires, pp. 177-224.

Göbel, B., 1994. El Manejo del Riesgo en la Economía Pastoril de Susques. Zooarqueol Camelidos 1, 43-56.

González, A.R., 1998. Cultura La Aguada. Arqueología y diseños. Filmediciones Valero, Buenos Aires.

González, A.R., Pérez Gollán, J.A., 1972. Argentina indígena, vísperas de la conquista. Paidós, Buenos Aires.

González, L.R., 2004. Bronces sin nombre. La metalurgia prehispánica en el noroeste argentino. Ediciones Fundación Ceppa, Buenos Aires.

Grayson, D.K., 1984. Quantitative Zooarchaeology. Topics in the Analysis of Archaeological Faunas. Academic Press, Orlando.

Hillson, S., 2005. Teeth. Cambridge University Press, Cambridge.

Izeta, A.D., 2004. Zooarqueología del Sur de los Valles Calchaquíes: Estudio de conjuntos faunísticos del Periodo Formativo. Facultad de Ciencias Naturales y Museo, Universidad Nacional de La Plata, La Plata.

Izeta, A.D., 2005. South American camelid bone structural density: what are we measuring? Comments on data sets, values, their interpretation and application. J. Archaeol. Sci. $1159-1168$.

Izeta, A.D., 2007. Zooarqueología del sur de los valles Calchaquíes (Provincias de Catamarca y Tucumán, República Argentina). British Archaeological Reports. John and Erica Hedges Ltd, Oxford.

Izeta, A.D., 2008. Late Holocene camelid use tendencies in two different ecological zones of Northwestern Argentina. Quaternary International 180, 135-144.

Izeta, A.D., Cortés, L.I., 2006. South American camelid palaeopathologies: examples from Loma Alta (Catamarca, Argentina). International Journal of Osteoarchaeology 16 269-275.

Izeta, A.D., Otaola, C., Gasco, A., 2009a. Osteometría de falanges proximales de camélidos sudamericanos modernos. Variabilidad, estándares métricos y su importancia como conjunto comparativo para la interpretación de restos hallados en contextos arqueológicos. Rev. Museo Antropol. 2, 169-180.

Izeta, A.D., Srur, M.G., Labarca, R., 2012. Guía de osteometría de camélidos sudaméricanos. Universidad Nacional de Córdoba, Córdoba.

Izeta, A.D., Urquiza, S.V., Baldini, L., 2009b. La arqueofauna del período Tardío en el NOA Una aproximación desde los conjuntos del sitio Molinos I (provincia de Salta, R. Argentina). Arqueología 15, 63-84.

Kent, J.D., 1982. The Domestication and Exploitation of the South American camelids: methods of analysis and their application to circum-lacustrine archaeological sites in Bolivia and Perú. Washington University.

Klein, R.G., Cruz-Uribe, K., 1984. The Analysis of Animal Bones from Archaeological Sites. The University of Chicago Press, Chicago.

Kuznar, L.A., 1990. Economic models, ethnoarchaeology, and pastoralism in the high sierra of the south central Andes. Anthropology. Northwestern University, Illinois.

Linnaeus, C., 1758d. Sistema Naturae per Regna Tria Naturae, Secundum, Classes, Ordines, Genera, Species, cum Characteribus, Differentiis, Synonymis, Locis. Editio Decima, Reformata. (Impensis Direct Laurentii. Stockholm, Sweden. Salvii. Holmiae (Sweden), 1758 pp.).

Lönnberg, E., 1913. Notes on guanacos. Ark. Zool. (Stockholm) 8 (19), 1-8.

Lumbreras, L.G., 2008. Los Orígenes de la Sociedad Andina. In: Contreras, C. (Ed.) Economía Prehispánica. BCRP, IEP, Lima, pp. 23-136.

Lyman, R.L., 1987. Archaeofaunas and butchery studies: a taphonomic perspective. Adv. Archaeol. Method Theory 10, 249-337.

Lyman, R.L., 1994. Vertebrate Taphonomy. Cambridge University Press, Cambridge.
Lyman, R.L., 2003. The influence of time averaging and space averaging on the application of foraging theory in zooarchaeology. J. Archaeol. Sci. 30, 596-610.

Lyman, R.L., 2008. Quantitative paleozoology. Cambridge University Press, Cambridge; New York.

Madero, C.M., 1993-94. Ganadería incaica en el noroeste argentino: análisis de la arqueofauna de dos poblados prehispánicos. Relac. Soc. Argent. Antropol. 19, 145-169.

Marean, C.W., Frey, C.J., 1997. Animal bones from caves to cities: reverse utility curves as methodological artifacts. Am. Antiq. 62, 698-711.

Menegaz, A., Salemme, M., Ortiz Jaureguizar, E., 1988. Una Propuesta de Sistematización de Caracteres Morfométricos de los Metapodios y las Falanges de Camelidae. In: Ratto, N., Haber, A. (Eds.), De Procesos, Contextos y Otros Huesos. FFyL-ICA, Buenos Aires, pp. 53-64.

Mengoni Goñalons, G.L., 1991a. Análisis de los Restos Óseos de Camélido Recuperados en la Localidad de "Las Pailas" (Salta), Buenos Aires.

Mengoni Goñalons, G.L., 1991b. La llama y sus productos primarios. Arqueología 1, 179-196.

Mengoni Goñalons, G.L., 1999. Cazadores de Guanacos de la Estepa Patagónica. Sociedad Argentina de Antropología, Buenos Aires.

Mengoni Goñalons, G.L., 2006-2010. Zooarqueología en la práctica: algunos temas metodológicos. Xama 19-23, 83-113.

Mengoni Goñalons, G.L., 2013. El aprovechamiento de fauna en sociedades complejas: aspectos metodológicos y su aplicación en diferentes contextos arqueológicos del NOA. In: Williams, V.I., Cremonte, M.B. (Eds.), Al borde del imperio, paisajes sociales, materialidad y memoria en áreas periféricas del noroeste argentino. Publicaciones de la Sociedad Argentina de Antropología, Ciudad Autónoma de Buenos Aires, pp. 311-396.

Mercolli, P.H., 2010. Estrategias de subsistencia en la Quebrada de Humahuaca, provincia de Jujuy. Dos casos de estudio relacionados al manejo ganadero y la trascendencia de la caza a través del tiempo en las sociedades humanas. In: Gutiérrez, M.A., De Nigris, M., Fernández, P.M., Giardina, M., Gil, A., Izeta, A.D., Neme, G., Yacobaccio, H.D. (Eds.), Zooarqueología a principios del siglo XXI. Aportes teóricos, metodológicos y casos de estudio. Ediciones del Espinillo, Buenos Aires, pp. 273-284.

Molina, G.I., 1782d. Saggio Sulla Storia Naturale del Chile. Tommaso d'Aquino, Bologna.

Morlan, R.E., 1994. Bison bone fragmentation and survivorship: a comparative method. J. Archaeol. Sci. 21, 797-807.

Murra, J., 2002. Rebaños y pastores en la economía del Tawantinsuyu, El mundo andino. Población, medio ambiente y economía. IEP-PUCP, Lima, pp. 308-327.

Nielsen, A.E., 2006. Plazas para los antepasados: descentralización y poder corporativo en las formaciones políticas preincaicas de los andes circunpuneños. Estud. Atacameños 31, 63-89.

Olivera, D.E., 1997. La importancia del recurso Camelidae en la puna de Atacama entre los 10.000 y 500 años a.P. Estud. Atacameños 14, 29-41.

Olivera, D.E., 2001. Sociedades Agropastoriles Tempranas: el Formativo Inferior del Noroeste Argentino. In: Berberian, E., Nielsen, A.E. (Eds.), Historia Argentina Prehispánica. Editorial Brujas, Córdoba, pp. 83-125.

Páez, M.C., Giovannetti, M., Raffino, R., 2012. Las pailas. Nuevos aportes para la comprensión de la agricultura prehispánica en el Valle calchaquí norte. Rev. Esp. Antropol. Am. 42, 339-357.

Pratolongo, G.J., 2008. Estudio de los Restos Faunísticos de dos Sitios Tardíos en el Valle de Yocavil, Provincia de Catamarca: Rincón Chico 15 y Las Mojarras 1. In: Tarragó, M.N. González, L.R. (Eds.), Estudios Arqueológicos en Yocavil. Asociación de Amigos del Museo Etnográfico, Buenos Aires, pp. 81-126.

Reitz, E.J., Wing, E.S., 1999. Zooarchaeology. Cambridge University Press, Cambridge.

Santillán de Andrés, S.E., 1982. La región del Valle calchaquí. Rev. Geogr. 95

Scattolin, M.C., 2006. De las comunidades aldeanas a los curacazgos en el noroeste argentino. Bol. Arqueol. PUCP 10, 357-398.

Scattolin, M.C., 2007. Santa Maria Antes del año mil. Fechas y Materiales Para una Historia Cultural. In: Williams, V.I., Ventura, B.N., Callegari, A.B.M., Yacobaccio, H.D. (Eds.), Sociedades Precolombinas Surandinas: Temporalidad, Interacción y Dinámica cultural del NOA en el ámbito de los Andes Centro-Sur, Buenos Aires, pp. 203-219.

Scattolin, M.C., Pereyra Domingorena, L., Cortés, L.I., Bugliani, M.F., Calo, C.M., Izeta, A.D., Lazzari, M., 2007. Cardonal: una aldea formativa entre los territorios de valles y puna. Cuad. Fac. Humanid. Cienc. Soc. 32, 211-225.

Sotomayor Berrío, M.A., 1984. La explotación ganadera en las comunidades campesinas. Allpanchis 20, 97-103.

Stahl, P.W., 1999. Structural density of domesticated south american camelid skeletal elements and the investigation of prehistoric andean ch'arki. J. Archaeol. Sci. 26, $1347-1368$

StatSoft, Inc., 2004. Electronic Statistics Textbook URL: www.statsoft.com.

Tarragó, M.N., 1980. Los asentamientos aldeanos tempranos en el sector septentrional del Valle calchaquí, provincia de Salta, y el desarrollo agrícola posterior. Estud. Arqueol. 5, 29-52.

Tarragó, M.N., 1992. El Formativo y el Surgimiento de la Complejidad Social en el Noroeste Argentino. Simposio Internacional "Arqueología Suramericana. Una Reevaluación del Formativo", Cuenca, Ecuador.

Tarragó, M.N., 2000. Chacras y Pukara. Desarrollos Sociales Tardíos. In: Tarragó, M.N. (Ed.), Los Pueblos Originarios y la Conquista. Editorial Sudamericana, Buenos Aires, pp. 257-300.

Tarragó, M.N., 2011. Poblados tipo pukara en yocavil. El plano de rincón chico 1 (catamaraca, Argentina). Estudios Sociales del NOA/nueva serie 11, pp. 33-61.

Tomka, S.A., 1992. Vicufias and llamas: parallels in behavioral ecology and implications for the domestication of andean camelids. Hum. Ecol. 20, 407-433.

Valencia, R.F.J., Lago, A.B., 1970. Relación suelo-morfología en el Valle calchaquí. Provincia de Salta, República Argentina. Rev. Asoc. Geol. Argent. 25, 71-85.

Vilá, B., 2012. Camélidos Sudamericanos. Eudeba, Buenos Aires. 
Vilá, B., 2014. Una aproximación a la etnozoología de los camélidos andinos. Etnoecológica $10,43-58$.

von den Driesch, A., 1976. A Guide to the Measurement of Animal Bones from Archaeological Sites. Peabody Museum of Archaeology and Ethnology, Harvard.

Wheeler, J.C., 1982. Aging llamas and alpacas by their teeth. Llama World 1, 12-17.

White, T.A., 1953. A Method of Calculating the Dietary Percentage of Various Food Animals Utilized by Aboriginal Peoples. Am. Antiq. 18, 396-398.

Williams, V., Villegas, M.P., Gheggi, M.S., Chaparro, M.G., 2005. Hospitalidad e intercambio en los valles mesotermales del noroeste argentino. Bol. Arqueol. PUCP 9, 335-372.

Wing, E., 1975. La domesticación de animales en los andes. Allpanchis 8, 25-44.

Yacobaccio, H.D., 2001. La Domesticación de Camélidos en el Noroeste Argentino. In: Berberian, E., Nielsen, A.E. (Eds.), Historia Argentina Prehispánica. Editorial Brujas, Córdoba, pp. 7-40.
Yacobaccio, H.D., Madero, C.M., Malmierca, M.P., 1998. Etnoarqueología de Pastores Surandinos. Grupo Zooarqueología de Camélidos, Buenos Aires.

Yacobaccio, H.D., Madero, C.M., Malmierca, M.P., Reigadas, M.d.C., 1997-1998. Caza domesticación y pastoreo de camélidos en la puna Argentina. Relac. Soc. Argent. Antropol. 22-23, 389-418.

Yacobaccio, H.D., Malmierca, M.P., 2006. The Role of the Challada in Llama Culling (Puna of Atacama, Argentina). In: Dransart, P. (Ed.), Kay Pacha. Cultivating earth and water in the Andes. Archaeopress, Oxford, pp. 151-156. 